\title{
Immunity of States for Noncommercial Torts: A Comparative Analysis of the International Law Commission's Draft
}

\begin{abstract}
The International Law Commission of the United Nations provisionally adopted a new codification of international law concerning foreign sovereign immunity. The ILC draft restricts foreign sovereign immunity in noncommercial tort suits, but its provisions for the enforcement of judgments give tort creditors in such cases little chance of enforcing a judgment against a recalcitrant foreign state. This Comment analyzes the extent to which the ILC draft provides immunity from adjudicatory and enforcement jurisdiction by comparing it with other attempts to codify foreign sovereign immunity, especially the United States' Foreign Sovereign Immunities Act, the United Kingdom's State Immunity Act, and the European Convention on State Immunity. The author argues that the ILC erred in attempting to create an enforcement rule applicable to all types of cases. Instead, the ILC should have adjusted the degree of immunity from measures of enforcement to reflect the different balance of interests involved in commercial cases and tort cases. Allowing execution of judgments against commercial property of a foreign state in noncommercial torts cases would fairly balance the interests of the foreign state, the forum state, and the claimant; in cases involving state-sponsored international terrorism, property of state-owned agencies should also be available for execution of judgments.
\end{abstract}

\section{INTRODUCTION}

International law on the immunities of states fron the jurisdiction of other states has been in flux for several decades. No general international convention has codified the law on the subject, and states have not followed any uniform practice in this area. ${ }^{1}$ Some states, most notably the Soviet Umion and other Eastern Bloc nations, still adhere to the doctrine that a sovereign state cannot be sued in the courts of another state without its consent. ${ }^{2}$ Although the United States was one of the first

1. Treaties, conventions, and international custom establish rules of international law. Courts will recognize as a rule of customary international law a settled practice among most nations that is "carried out in such a way, as to be evidence of a belief that this practice is rendered obligatory by the existence of a rule of law requiring it." North Sea Continental Slielf (W. Ger. v. Neth. \& Den.), 1969 I.C.J. 3, 44 (Judgment of Feb. 20).

2. Eastern Bloc countries profess to adliere to the rule of absolute iminunity. See U.N.

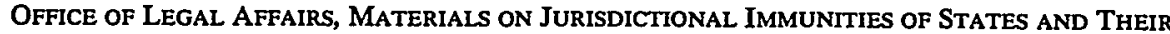


countries to forınulate this doctrine of absolute immunity, ${ }^{3}$ it today joins most developed western nations in recognizing the immunity of other states only im limited circumstances. ${ }^{4}$ Developing nations are split on the subject. ${ }^{5}$ More confusing still, nations that have adopted a restrictive view of sovereign immunity ${ }^{6}$ do not agree on what exceptions to immumity they should recognize. International practice has been in this uncertain state since at least the early 1970's.

Most of the countries that recently adopted legislation restricting sovereign immumity have provided an exception for actions arising out of tortious conduct by a foreign state or its pohitical subdivisions, instrumentalities, or agencies that causes personal injury or death or damage to

ProperTY, at 6 (Byelorussian Soviet Socialist Republic); 14-15, 82-83, 564-67 (Czechoslovakia); 8485 (East Germany); 17-19, 575-77 (Hungary); 90-91 (Poland); 27, 594-96 (Romania); 40, 92, 616-19 (USSR), U.N. Doc. ST/LEG/SER.B/20, U.N. Sales No. E/F.81.V.10 (1982) [hereinafter MATERIALS ON IMMUNITIES]. This claim is somewhat illusory. The Soviet Union, for example, conducts much of its foreign business through its Trade Delegations. Under the provisions of bilateral treaties, these delegations are subject to the adjudicatory and enforcement jurisdiction of the forum state. See id. at $134-50$ (presenting excerpts from various Soviet treaties). Since this amounts to consent to suit, it does not as a doctrinal matter derogate from the principle of absolute immunity. As a practical matter, however, the Soviet example demonstrates that immunity cannot be absolute in any literal sense.

MATERIALS ON IMMUNITIES is an invaluable source of materials on state practice with respect to immumity. The book contains, among other things, texts of national legislation, official records and correspondence, treaty provisions, and transcripts of relevant case decisions.

3. See Sucharitkul, Second Report on Jurisdictional Immunities of States and Their Property, U.N. Doc. A/CN.4/331 (1980), reprinted in [1980] 2 Y.B. INT'L L. CoMM'N, pt. 1, at 199, 217, U.N. Doc. A/CN.4/SER.A/1980 (discussing the impact of The Scliooner Exchange v. McFaddon, 11 U.S. (7 Cranch) $116(1812))$.

4. See, e.g., Foreign Sovereign Immunities Act, 28 U.S.C. $\$ \S 1330,1602-1611$ (1982) (United States); State Immunity Act, 1978, ch. 33 (United Kingdom); European Convention on State Immunity, May 16, 1972, Europ. T.S. No. 74 (Council of Europe); see also Canada State Immunity Act, ch. 95, 1980-1981-1982 Can. Stat. 1949, art. 6(1982); MATERIALS ON IMMUNITIES, supra note 2, at 5-6 (Austria), 84 (Finland), 587-89 (Netherlands), 19 (Norway), 34-40 (South Africa), 602-04 (Sweden), 88 (West Germany).

5. For examples of countries that regard immunity as basically absolute, see MATERIALS oN IMMUNITIES, supra note 2, at 4 (Argentina), 562-63 (Brazil), 13 (Chile), 79 (Colombia), 567-69 (Ecuador), 601-02 (Sudan), 604-07 (Syria), 610-14 (Trinidad \& Tobago), 638-40 (Venezuela). Some of these countries may restrict immunity based on a principle of reciprocity. For countries that recognize a restricted version of immumity, see id. at $74-75$ (Barbados), 569-71 (Egypt), 89-90 (Greece), 581-84 (Madagascar), 20-27 (Pakistan), 28-34 (Singapore), 91-92 (Surinam), 641-45 (Yugoslavia).

6. "Restrictive immunity" is often used to denote the principle that states are not immune with respect to the conduct of their commercial activities in other countries. See Letter of Acting Legal Adviser Jack B. Tate to Department of Justice, 26 DEP'T ST. BuLI. 984 (1952) [hereinafter Tate Letter]. The term "restrictive inmunity" is also used more loosely to refer to any derogation from an absolute view of imınunity. See Sucharitkul, Fifth Report on Jurisdictional Immunities of States and Their Property, U.N. Doc. A/CN.4/363 (1983), reprinted in [1983] 2 Y.B. INT'L L. COMM'N, pt. 1, at 41, U.N. Doc. A/CN.4/SER.A/1983 [hereinafter Fifth Report of the Special Rapporteur] (referring to "countries where judicial practice has tended to favour a less absolute or a more restrictive principle of State inmunity"). Throughout this Comment "restrictive immunity" will be used in this looser sense, encompassing commercial activities and other exceptions, unless otherwise indicated. 
tangible property-so-called "noncommercial torts."7 Treatment of noncommercial torts varies from state to state among countries that have not recently recodified their sovereign immunity doctrine. ${ }^{8}$ Thus, the status of state immunity for noncommercial torts in international law is unsettled.

In 1977, the United Nations imvited the International Law Commission (ILC) to consider the question of immumities of states and their property. ${ }^{9}$ The ILC began its consideration of the topic in 1978, and Mr. Sompong Sucharitkul of Thailand was appointed Special Rapporteur. ${ }^{10}$ The ILC produced a set of draft articles on immunities, which was presented to the General Assembly in 1986. ${ }^{11}$ These articles could form the basis of a comprehensive convention on immunities of states and their property. ${ }^{12}$

The ILC frequently concentrates on codification of customary international law. ${ }^{13}$ As noted above, however, international practice with respect to immunities is insufficiently uniform to reach the level of accepted custoin. Thus, the ILC's draft articles are more of a "progressive development" of international law than a codification of existing practice. ${ }^{14}$ Many of these progressive developments were very controver-

7. The term "noncommercial torts" excludes injury arising from contractual or business relations. States that have recently codified a noncommercial tort exception include the United States, Foreign Sovereign Immunities Act, 28 U.S.C. \& 1605(a)(5) (1982), United Kingdom, State Inmunity Act, 1978, ch. 33, art. 5, Canada, State Immunity Act, ch. 95, 1980-1981-1982 Can. Stat. 1949, art. 6 (1982), Singapore, State Immunity Act, 1979, art. 7, and South Africa, Foreign Sovereign Immunity Act, 1981, art. 6; see also European Convention on State Inununity, May 16, 1972, art. 11, Europ. T.S. No. 74, at 4. Pakistan, however, did not include a noncommercial torts exception in its recent codification, which in other respects closely resenbles the codifications of the other Commonwealth countries. See MATERIALS on IMMUNITIES, supra note 2, at 20-27.

8. Fifth Report of the Special Rapporteur, supra note 6, at 25, 41-42.

9. G.A. Res. 151, 32 U.N. GAOR Supp. (No. 45) at 214-15, U.N. Doc. A/32/45 (1978). The International Law Commission is an organ of the United Nations responsible for "the proniotion of progressive development of international law and its codification," Statute of the International Law Commission, G.A. Res. 174(II), art. 1, U.N. Doc. A/519 (1947) [hereinafter ILC Statute] in accordance with provisions of U.N. ChARTER art. 13, para. 1 (empowering the General Assenibly to promote the development of international law).

10. Report of the International Law Commission on the Work of Its Thirtieth Session, 33 U.N. GAOR Supp. (No. 10) at 383-84, U.N. Doc. A/33/10 (1978).

11. Report of the International Law Commission on the Work of Its Thirty-Eighth Session, 41 U.N. GAOR Supp. (No. 10), U.N. Doc. A/41/10 (1986) [hereinafter 1986 ILC Report].

12. Sucharitkul, Eighth Report on Jurisdictional Immunities of States and Their Property, U.N. Doc. A/CN.4/396, at 7 (1986) [hereinafter Eighth Report of the Special Rapporteur].

13. United Nations Institute For TRAining \& RESEARCh, The INTERNATIONAL LAW Commission: The NeEd For A New Direction, 4-16, U.N. Sales No. E.81.XV.PE/1 (1981).

14. As the ILC statute illustrates, the distimction between codification and progressive development is a fine one:

The expression "progressive development of international law" is used for convenience as meaning the preparation of draft conventions on subjects which have not yet been regulated by international law or in regard to which the law has not yet becn sufficiently developed in the practice of States. Similarly, the expression "codification of international law" is used for convenience as meaning the nore precise formulation and systentatization 
sial during the ILC debates and may not be accepted by portions of the international commumity.

The ILC draft will be the focus of debate on the subject of immunities of states. This Comment addresses some of the most disputed segments of that draft, namely, the articles dealing with noncommercial torts and enforcement of judgments on property of foreign states by successful tort plaintiffs. Those provisions, particularly the ones concerning enforcement, were hotly debated and remain very controversial. ${ }^{15}$ They are also susceptible of improvement.

The first two parts of this Comment are primarily descriptive and comparative. Part I examines the scope of the ILC draft's noncommercial torts exception to immunities of foreign states from the adjudicatory jurisdiction of forum states. By limitimg immunity from jurisdiction for noncommercial torts, the ILC explicitly recognized the rights of tort victims to compensation from foreign states. However, the ILC's enforcement provisions substantially lessen the value of the jurisdictional provisions for tort claimants by severely restricting the types of foreign property available for execution of judgments. Part II discusses the diffculties tort claimants would encounter enforcing judgments under the ILC's general enforcement provisions. Parts I and II both compare the ILC draft to recent attempts to codify sovereign immunity doctrine by the United States, the United Kingdom, and the Council of Europe.

Part III argues that the ILC's enforcement provisions strike a poor balance between the interests of the foreign state, the forum state, and individual claimants. While the ILC's decision to endorse broad immunity from measures of enforcement might be justified in some cases, it is not justified in the case of noncommercial torts, particularly when the tort is an act of international terrorism. Part IV describes an alternative structure for the enforcement provisions that tailors the scope of immumity from enforcement measures to the type of claim. Such a structure would make tort judgments more enforceable than under the ILC draft.

of rules of international law in fields where there already has been extensive state practice, precedent and doctrine.

ILC Statute, supra note 9, art. 15. Under this definition, certain provisions of the ILC draft are probably best characterized as codifications, like those relating to immunity for intangible injuries. Many other provisions could be more accurately characterized as "progressive developments." Professor McCaffrey, Chairman of the ILC, notes that in practice thc Commission pays little attention to whether the provisions it adopts could be described as "codifications" or "progressive developments." Comments froin Professor Stephen McCaffrey to the author (Dec. 9, 1987) (on file with author).

15. See, e.g., Report of the International Law Commission on the Work of Its Thirty-Seventh Session, 40 U.N. GAOR Supp. (No. 10) at 133-40, U.N. Doc. A/40/10 (1985) [hcreinafter 1985 ILC Report]. 


\section{I}

\section{JURISDICTIONAL IMMUNITIES FOR NONCOMMERCIAL TORTS}

The Speeial Rapporteur first proposed that the ILC adopt an exception to immunity for noncommercial torts in $1983 .{ }^{16} \mathrm{He}$ found that although customary international law did not provide a basis for such an exception, courts in certain countries have recently extended jurisdiction over foreign sovereigns in cases involving personal injury or property damage. ${ }^{17}$ As "impelling reasons" for this trend, he noted that the local forun is generally the most convenient and practical, innocent victims might otherwise have no legal remedy, and the sovereignty of the state responsible for the damage is not directly at stake in these cases. ${ }^{18}$

Along with his report, the Special Rapporteur suggested a draft provision covering a noncommercial tort exception to immunity fron jurisdiction. Although the ILC somewhat altered the langnage, the basic structure of the article passed unchanged into the final draft, which reads:

Unless otherwise agreed between the States concerned, the immunity of a State cannot be invoked before a court of another State which is otherwise coinpetent in a proceeding which relates to compensation for death or injury to the person or damage to or loss of tangible property if the act or onission which is alleged to be attributable to the State and which caused the death, injury or damage occurred in whole or in part in the territory of the State of the forum and if the author of the act or omission was present in that territory at the time of the act or omission. ${ }^{19}$

The following sections compare these ILC draft provisions to prominent new state codifications, particularly the United States' Foreign Sovereign Immunities Act (FSIA), ${ }^{20}$ the United Kingdon's State Immunity Act, ${ }^{21}$ and the European Convention on State Immunity. ${ }^{22}$ The purpose of this exammation is to determine as closely as possible the scope of the ILC's noncommercial tort exception, and to discover how it differs from other attempts to address the same problem. These sections demonstrate that despite differences of perception and approach, the ILC's provision is about as generous an exception to the principle of immumity as other recent codifications of sovereign immunity doctrine.

\footnotetext{
16. Fifth Report of the Special Rapporteur, supra note 6, at 38-46.

17. Id. at 39.

18. Id. at $39-40$.

19. 1986 ILC Report, supra note 11, art. 13, at. 16.

20. 28 U.S.C. $\S \S 1330,1602-1611$ (1982).

21. State Immunity Act, 1978, ch. 33.

22. European Convention on State Immunity, May 16, 1972, Europ. T.S. No. 74.
} 


\section{A. Analysis of Individual Clauses}

\section{1. "Unless otherwise agreed between the States concerned ..."}

This clause is unlike the provisions of national codifications, refiecting the differing concerns of the ILC and national legislatures. The ILC's noncommercial tort provision does not attempt to create an independent cause of action enforceable by private individuals. The purpose of the ILC's codification as a whole is to define the limits of jurisdiction states may exercise over other states and their property. Since a state may choose not to exercise the full extent of its jurisdictional authority, it may also agree to limit the exercise of its authority through agreements with other states.

In contrast, the FSIA does not address the effect of contrary agreeinents in its section on noncommercial torts. Instead, the general provisions of section 1604 govern the impact of other agreements on the entire FSIA. That section inakes the effect of the FSIA "[s]ubject to existing international agreements to which the United States is a party at the time of enactment of this Act."23 Although the FSIA expressly excepts only preexisting international agreements from coverage of the Act, general principles of U.S. foreign relations law direct that any subsequent selfexecuting treaty would supersede inconsistent portions of the FSIA. ${ }^{24}$

The State Immunity Act's provisions on the effect of contrary agreements differ from both the ILC draft and the FSIA. The Queen, by Order in Council, may restrict or expand the immumities of states when it appears that the provisions of any treaty or agreement are contrary to the Act. $^{25}$ Although subsequent as well as preexisting agreements may limit the application of the Act, the executive must act in order to recognize the conflict. Courts thus do not have final authority to resolve confiicts between the Act and other agreenents.

It is not surprismg that the ILC draft and the national codifications differ im their treatınent of contrary agreements. It is important for an international convention or codification of international law to specify whether bilateral agreenents inay derogate from its rules. ${ }^{26}$ This is less

23. 28 U.S.C. $\$ 1604$ (1982). This limitation applies to the noncommercial tort exception. See H.R. REP. No. 1487, 94th Cong., 2d Sess. 17, reprinted in 1976 U.S. CODE CONG. \& ADMIN. NEWS 6604, 6616 [heremafter HousE REPORT].

24. RESTATEMENT (SECOND) OF FOREIGN RELATIONS \& 141(1) (1965).

25. State Immumity Act, art. 15(1)(b).

26. Treaties can ordmarily suspend rules of international law as between the parties. Only preemptory norms of general international law ("jus cogens") cannot be altered by treaty. The Vienna Convention on the Law of Treaties defines a preemptory norm of general international law as "a norm accepted and recognized by the international community of States as a whole as a norm from which no derogation is permitted and which can be modified only by a subsequent norm of general international law having the same character." Vienna Convention on the Law of Treaties, May 23, 1969, art. 53, 1155 U.N.T.S. 331, 344. 
important when drafting a national statute, since nationally applicable conflict of law principles will determine the effect of subsequent agreements. Furthermore, international conventions generally are concerned more with broad principles than with the ways im which individual countries implement them. Both pieces of domestic legislation, however, concern judicial administration: the "contrary agreements" clauses limit the judiciary's power to override the provisions of the Acts on the basis of conflicts with other agreements. Consequently, because the purposes of the ILC provisions differ from those of the State Immunity Act or the FSIA, it would be mappropriate for the ILC's language regarding contrary agreements to parallel the language of the other codifications.

\section{2. ". . . the immunity of a State cannot be invoked before a court of another State which is otherwise competent. .."}

The "otherwise competent" clause is remarkable only because it is unnecessary. A court must determine that it has valid jurisdiction before it can reach the question of whether a particular state is immune from its jurisdiction. For example, even though the FSIA does not expressly provide that the court must be "otherwise competent," U.S. courts nevertheless examine whether or not they have in personam jurisdiction over the foreigu state or entity. ${ }^{27}$

Additionally, the Special Rapporteur noted that exercise of jurisdiction in a noncommercial tort case is generally proper at the place where the wrong was committed. ${ }^{28}$ Since the ILC's exception for noncommercial torts does not apply unless the tortious act occurred in the fornm state, ${ }^{29}$ the "otherwise competent" language is doubly unnecessary: in any situation where the ILC's noncommercial torts exception apphes, a court would have jurisdiction by virtue of the location of the tortious action. The "otherwise competent" clause, therefore, does not appear to be particularly critical, though it does no harm.

3. ". . in a proceeding which relates to compensation for death or injury to the person or damage to or loss of tangible property..."

This clause contains the most innportant limitations on the noncommercial tort exception. The Special Rapporteur noted: "Damage to reputation or defamation is not personal mjury im the physical sense, nor can

27. See, e.g., Texas Trading \& Milling Corp. v. Federal Republic of Nig., 647 F.2d 300, 313-15 (2d Cir. 1981) (court examined the facts of the case to determine if they established the constitutional requirements for the exercise of personal jurisdiction apart froin the question of whether the provisions of the FSIA applied), cert. denied, 454 U.S. 1148 (1982).

28. Fifth Report of the Special Rapporteur, supra note 6, at 39.

29. See 1986 ILC Report, supra note 11, art. 13; see also infra text accoinpanying notes 39-43. 
interference with contract rights or any rights, including econounic or social rights, be viewed as damage to tangible property."30 Consequently, libel, civil rights, and contract claims are all outside the scope of this exception.

The ILC's reason for excluding commercial and intangible injuries is not clear from its records. It may be that the Commission simply wanted to limit the scope of the tort exception, and this seemed to be a good place to draw the line. Moreover, those states that recognize a torts exception have not included commercial or intangible mjuries; thus international practice provided no basis for himiting immunity in such cases. Most recent codifications that contain a tort exception limit it to tangible, noncommercial injuries. For example, article 5 of the State Immunity Act provides that states are not immune in "proceedings in respect of: (a) death or personal injury; or (b) damage to or loss of tangible property." 31 The European Convention restricts immunity in proceedings relating to "mjury to the person or damage to tangible property." 32 The FSIA tort exception applies in actions for death, personal injury, or damage to or loss of property, and expressly does not apply in "any claim arising out of mahicious prosecution, abuse of process, libel, slander, misrepresentation, deceit, or interference with contract rights." ${ }^{33}$

The draft convention proposed in 1982 by the International Law Association, an independent scholarly organization, ${ }^{34}$ does not linnit the tort exception to tangible noncommercial injuries. ${ }^{35}$ The ILA's proposal will undoubtedly remain in the minority, however. Even countries that have been most willing to restrict sovereign immunity have not been

30. Fifth Report of the Special Rapporteur, supra note 6, at 45. Professor Badr made a similar point more obscurely by stating that "non-material injury not connected to a material injury is not covered by the rule of non-immumity." G. BADR, STATE IMMUNITY 119 (1984). The more interesting question, which none of the codifications directly address, is whether the rule of nonimmunity covers a nonmaterial loss that is connected to a inaterial injury. In the United States, for example, a tort claimant may ask for reparations for loss of future earnings and sinilar claims of an "economic" nature. Under the ILC draft, and under the FSIA, there does not appear to be any direct bar to awarding damages for these losses in a suit against a foreign state.

31. State Immunity Act, 1978, ch. 33, art. 5. The infuence of the State Immunity Act on the ILC draft's language is apparent.

32. European Convention on State Imınunity, May 16, 1972, art. 11, Europ. T.S. No. 74, at 4.

33. FSIA, 28 U.S.C. $\S 1605$ (a)(5)(B) (1982).

34. The International Law Association was founded in 1873, and has no formal ties to the International Law Commission or the United Nations, although the provisions of its charter express a purpose akin to the ILC's: the "Reform and Codification of the Law of Nations." INTERNATIONAI LAW ASSOCIATION, REPORT OF THE EIGHTEENTH CONFERENCE 5, 9 (resolution No. 6) (1900).

35. The International Law Association's suggested wording for the tort exception was "Where the cause of action relates to ... [d] eath or personal injury; or ... [d]amage to or loss of property." INTERNATIONAL LAW ASSOCiation, RePORT OF THE SiXtieth CONFERENCE 8 (resolution No. 6) (1983), quoted in Fifth Report of the Special Rapporteur, supra note 6, at 45. The Association's language does not limit the tort exception to tangible property. 
eager to restrict immunity for intangible injuries and commercial torts. ${ }^{36}$ Most countries probably felt that a contrary rule would simply cause too many problems for the conduct of foreign relations.

Furthermore, sovereign immunity is based upon recognition of the sovereign equality of nations. Since few countries have waived doniestic sovereign immunity for intangible losses, ${ }^{37}$ failure to extend immumity to foreign sovereigns for such losses would appear to deny the equality primciple. This seems to have been the rationale for the FSIA's limitation on the tort exception. ${ }^{38}$ While it is possible to argue that the rationale for broad doinestic immunity fronı such suits does not apply to foreign sovereign immunity, ${ }^{39}$ the appearance of less favorable treatment for foreign states would be undesirable. Certainly it is a factor to consider when adopting a rule of immunity.

4. ". . If the act or omission which is alleged to be attributable to the State and which caused the death, injury or damage occurred in whole or in part in the territory of the State of the forum ....".

This clause contains three requirenients that a claimant must satisfy before a state may be denied immunity: the claimant must allege (1) that the act or omission was attributable to the foreign state; (2) that it caused the injury; and (3) tliat it occurred at least partly in the foruin State.

The ILC's draftimg committee acted with needless caution in including the "alleged to be attributable to the State" langnage. ${ }^{40}$ Neither the

36. The clause's limitation was one of the few opportunities the ILC had to mirror a position common in international practice. See supra note 14 and accompanying text.

37. Even the United States, which restricted its domestic sovereign immunity more than 40 years ago, has not waived its immunity with regard to imtangible imjuries. Federal Tort Claims Act, 28 U.S.C. $\S 2680$ (h) (1982).

38. See HouSE REPORT, supra note 23, at 21, reprinted in 1976 U.S. CODE CONG. \& ADMIN. NEws at 6620: "The exceptions provided in subparagraphs (A) and (B) of section 1605(a)(5) correspond to many of the claims with respect to which the U.S. Government retains immunity under the Federal Tort Claims Act, 28 U.S.C. 2680 (a) and (h)."

The Special Rapporteur also noted "an apparent parallel" between the immunities of local and foreign sovereigns, but cautioned that "the analogy cannot be stretched to its logical conclusion." See Sucharitkul, Seventh Report on Jurisdictional Immunities of States and their Property, U.N. Doc. A/CN.4/388, at 25 (1985) [heremafter Seventh Report of the Special Rapporteur].

39. Foreign sovereign immunity need not mirror domestic sovereign immunity. While the absence of a domestic sovereign immunity principle might cripple a state's ability to perform routine governmental functions, the lack of coextensive foreign sovereign immunity would not injure a foreign state to the same degrec. Foreign states simply do not have the same massive exposure to liability as domestic governments because they necessarily have fewer contacts with the local citizens. Since the principle of equality should only require that countries in like situations be treated alike, lunitations on foreign sovereign immumity more stringent than those on domestic sovereign immunity would not seriously jeopardize the principle of equality.

40. The original wording of this article was not changed until after the submission of the Special Rapporteur's Eighth Report. 
State Immunity Act nor the original draft of the ILC's article ${ }^{41}$ contain such a requirement. While a literal reading of both these articles would allow a court to disregard immunity where the plaintiff does not allege that the foreign state caused the injury, it is difficult to inagine such a case arising. If the plaintiff does not allege wrongdoing by the foreign state, the state would not be a party to the case in the first place.

The causation requirement is a necessary part of any inımunity exception. Without the requirenient of a nexus between the alleged wrongdoing and the injury suffered, foreign states could be subject to frivolous suits despite the elaborate limitations on the types of injuries that qualify for the tort exception.

Finally, the ILC draft expressly provides that the act or onission must take place in part, but need not take place entirely, in the forum State. The FSIA, State Immunity Act, and European Convention all require that the act, omission, or facts take place in the forum State, but none contaim the "in whole or in part" language.

This last provision is significant because it recognizes, as its counterparts do not, that many acts nay combine to cause a tortious injury, and some of those acts may occur in different countries. If a court inust select a single act as the relevant one for determining where a tort occurred, its decision may be quite arbitrary. For example, in Letelier $v$. Republic of Chile, ${ }^{42}$ the District Court for the District of Columbia found that the tort exception of the FSIA applied when a state sent assassins to the forum state. The Court of Appeals for the Seventh Circuit, however, later criticized Letelier as an overbroad reading of section 1605 that improperly focused on where the injury occurred rather than where the tortious act took place. ${ }^{43}$ It is more accurate, however, to view the injury in Letelier as resulting from a complex tortious act, part of which took place in Chile (the decision to assassinate Letelier) and part of which took place in the United States (the actual assassination). The "in whole or in part" language in the ILC draft would thus make it easier for a court to consider the complexities of tortious actions than the corresponding provisions of the FSIA.

41. For the original draft of this article, see Fifth Report of the Special Rapporteur, supra note 6 , at 46.

42. 488 F. Supp. $665,671-74$ (D.D.C. 1980).

43. Frolova v. Union of Soviet Socialist Republics, 761 F.2d 370 (7th Cir. 1985). The court stated: "At first blush, it appears that there is jurisdiction if the injury, as here, occurs in this country, regardless of whether the tortious act causing the injury [did]. At least [the Letelier court] has read $\S 1605(a)(5)$ this broadly, but this interpretatiou has been rejected ...." Id. at 379 (citations omitted). 
5. ". . . and if the author of the act or omission was present in that territory at the time of the act or omission."

This clause attempts to restrict the extraterritorial effect of the noncommercial torts exception. It limits application of that exception to instances where the tortfeasor is in the forum state at the time the act or omission occurred. Neither the FSIA nor the State Immunity Act contain an analogous provision, ${ }^{44}$ though the European Convention does. ${ }^{45}$ It is possible that the people who worked on the two international codifications had more background in international law and were inore concerned with the problem of extraterritorial jurisdiction than those who drafted the national statutes. Nevertleless, this "presence" requirement is not defensible.

In the ILC debates on this provision, soine members advocated deleting the requirement that the tortfeasor be in the foruin state when the act occurs in order to eliminate immumity for transfrontier torts. ${ }^{46}$ These are torts perpetrated in one state the effects of which are felt in another, like a shot fired across state lines. The Commission apparently felt that to deny immumity im sucli cases would leave states open to hability for purely criminal or political acts. ${ }^{47}$

The ILC did not provide immunity for all criminal or political acts that cause injury, however: a foreign state would not be immune for a

44. However, the FSIA has been interpreted to require that the tortious act occur in the United States. House REPORT, supra note 23, at 21, reprinted in 1976 U.S. CODE CONG. \& ADMIN. NEws at 6619 ("the tortious act or omission inust occur within the jurisdiction of the United States"); see also Frolova, 761 F.2d at 379 (refusing to apply FSIA's noncommercial torts exception in a case where the injury occurred in the United States bnt all of the alleged tortious acts occurred in the Soviet Uinion).

For a different view of the requirement that the tortious act or omission must occur in the United States, see Amerada Hess Shipping Corp. v. Argentine Republic, 830 F.2d 421 (2d Cir. 1987) (refusing iminunity in a suit involving the boinbing of a Liberian vessel on the high seas near Argentine waters during the Falklands war). The Second Circuit, however, based its decision on the grounds that the FSIA did not govern suits brought against foreign sovereigns for breaches of the law of nations under the Alien Tort Claims Act. This reasoning is difficult to reconcile with the Supreme Court's view that the FSIA "contains a coniprehensive set of legal standards governing claims of immunity in every civil action against a foreign state or its political subdivisions, agencies, or instrumentalities." Verlinden B.V. v. Central Bank of Nig., 461 U.S. 480, 488 (1983).

45. European Convention on State Immunity, May 16, 1972, art. 11, Europ. T.S. No. 74, at 4.

46. Report of the International Law Commission on the Work of Its Thirty-Fifth Session, 38 U.N. GAOR Supp. (No. 10) at 36, U.N. Doc. A/58/10 (1983) [hereinafter 1983 ILC Report].

47. Id. The ILC report does not indicate which nembers wanted to exclude liability for criminal and political acts.

A U.S. State Department representative recently testified before Congress that neither Congress nor the Executive originally conteniplated that tort claims based on intentional state wrongdonig would be allowed under the FSIA. She did not, however, propose that the FSIA be revised to prevent such suits. See Foreign Sovereign Immunities Act: Hearing on H.R. 1888 and H.R. 1149, Before the Subcomm. on Administrative Law and Government Relations of the House Comm. on the Judiciary, 100th Cong., 1st Sess. 32-33 (1987) (testimony of Elizabeth Verville, Deputy Legal Adviser, Department of State) [hereinafter State Department Response to H.R. 1888]. 
criminal tort under the ILC provision if its agent met the presence requirement. Thus, potential liability for crimmal or political acts does not justify the ILC's special rule for transfrontier torts. Liability should not hinge on what side of the border the tortfeasor happened to be standing at the time she fired the shot. Or, to use a more plausible example, Country $X$ should not be immune from suit if its agents sent a letter bomb through international mail, when it would not be immune if its agents planted the same bomb inside Country $Y$ directly. The distinction is arbitrary.

\section{B. Jurisdictional Immunities of Political Subdivisions, Agencies, and Instrumentalities of States}

The provisions of the noncommercial tort exception examined above address the immumities of states. The Commission separately addressed the extent to which those provisions apply in suits against state agencies, instrumentalities, or political subdivisions. Because state agencies (such as trade delegations) ${ }^{48}$ and state-owned instrumentalities (such as national airlmes) are apt to have a more extensive presence in foreign states than representatives of the government itself, the extent of their immunity is particularly important.

Article seven of the ILC draft provides:

[A] proceeding before a court of a State shall be considered to have been instituted against another State when the proceeding is instituted against one of the organs of that State, or against one of its political sub-divisions or agencies or instruinentalities in respect of an act performed in the exercise of sovereign authority, or against one of the representatives of that State in respect of an act performed in his capacity as a representative, or when the proceeding is designed to deprive that other State of its property or of the use of property in its possession or control. ${ }^{49}$

Since this language grants political subdivisions, agencies, and instrumentahities immunity for acts performed in the exercise of "sovereign" authority, their immunity is functional rather than inherent.

48. The Soviet Union, for example, has entered numerous treaties concerning the immunities of its trade delegations. See MATERIALS ON IMMUNITIES, supra note 2, at 134-50.

49. 1986 ILC Report, supra note 11, at 12.

50. This article of the ILC draft is unclear in two inajor respects. First, the term "political subdivision" is undefined. While the separate states of a federal union such as Australia, the Federal Republic of Germany, or the United States are probably "political subdivisions" within the meaning of this clause, it is not clear whether counties, cities, or parishes are also included. Second, the reference to acts "performed in the exercise of sovereign authority" is ambiguous. As the United States Supreme Court recently rediscovered in a different context, attempts to distinguish between acts of sovereign authority and other types of government activities are difficult if not hopeless. See Garcia v. San Antonio Metro. Transit Auth., 469 U.S. 528 (1985), overruling National League of Cities v. Usery, 426 U.S. 833 (1976) (rejecting Usery's standard of immunity for "traditional governunental functions" as "unworkable"). 
The FSIA does not expressly limit political subdivisions and agencies of foreign states to functional immunity. It instead provides that a "foreign state" for the purposes of the Act also includes "a political subdivision of a foreign state or an agency or instrumentality of a foreign state." 51 By contrast, both the State Immunity Act $^{52}$ and the European Convention ${ }^{53}$ contain provisions similar to article seven of the ILC draft. Thus, the FSIA appears to grant subdivisions and agencies of foreign states much wider immunity than the other codifications.

The difference in the scope of immunity for subdivisions and agencies under these various codifications is inore apparent than real, however. The European Convention's language is instructive: it provides agencies with functional immunity by stating that "courts inay not entertain proceedings in respect of acts performed by the entity in the exercise of sovereigu authority (acta jure imperii)."54 Like each of the other codifications, the European Convention generally atteinpts to codify the restrictive theory of sovereign immunity, ${ }^{55}$ which is primarily grounded on the distinction between acta jure imperii, for which the state is immune, and acta jure gestionis, for which it is not. ${ }^{56}$ Under each of these codifications, the state itself effectively has only functional immunity. Consequently, if an agency can be sued like an ordinary person except when it performs acts of governmental authority (as the ILC draft provides) or when it performs acta jure imperii (as the European Convention states), the agency in fact has exactly the sanie immunity as that given to states theinselves. The FSIA is thus different froin the other codifications only because it explicitly recognizes that the functional immunity of agencies and subdivisions is no less extensive than the immunity of the state itself.

The ILC draft clearly extends subdivisions and agencies the same immunity for noncommercial torts it extends foreign states, since it does not recognize immunity for such torts, even for governinental actions. The Special Rapporteur explicitly refused to extend the distinction between acta jure imperii and acta jure gestionis to nonconmercial tort actions, finding no primcipled reason for denying relief to a tort victim injured by a foreign goverument acting in its sovereign capacity while allowing rehef to a tort victim injured by a foreign governınent acting in

51. FSIA, 28 U.S.C. § 1603(a) (1982).

52. State Immunity Act, 1978 , ch. 33 , art. 14.

53. European Convention on State Immunity, May 16, 1972, art. 27, Europ. T.S. No. 74, at 11.

54. Id.

55. "Restrictive theory" is used here in the narrow sense. See supra note 6.

56. Generally speaking, acta jure imperii are exercises of sovereign authority or performance of governnental functions. Acta jure gestionis are conınercial activities which private persons as well as governnients can perform. See Tate Letter, supra note 6, at 984. 
its commercial capacity. ${ }^{57}$ Thus, agencies of the foreign state have no immunity for noncommercial torts, even if the agency was exercising governmental authority.

\section{Summary of Provisions on Jurisdictional Immunities}

A careful analysis of the ILC's provisions on jurisdictional immumties for noncommercial torts demonstrates that they are not a radical departure from the analogous sections of the FSIA, the State Immunity Act, or the European Convention. While some language in the ILC draft tends to restrict immunity more than the other codifications, ${ }^{58}$ other clauses offer more expansive immunity. ${ }^{59}$ The key provisions are the same in each of the codifications: the noncommercial tort exception is recognized; it extends to actions for personal injury or damage to tangible property, but not defamation or economic loss; ${ }^{60}$ it apphes regardless of the nature of the governmental act; ${ }^{61}$ and the political subdivisions, agencies, and instrumentalities of foreign states have the same immunity as states themselves. ${ }^{62}$

\section{II}

\section{IMMUNITY FROM ENFORCEMENT OF JUDGMENTS}

The ILC's restrictive approach to jurisdictional immunity contrasts sharply with its approach to imniunity from measures of enforcement. The Commission treats jurisdictional immunity and immunity from measures of enforcenient as separate issues. This allows a court to deny a foreign state's claim to immunity from jurisdiction in a case, but to accept the state's claim of immunity when the successful plaintiff attempts to enforce the judgment. Almost all states, mcluding those that restrict the principle of immunity, provide broader immunity from measures of enforcenient than from adjudicatory jurisdiction. ${ }^{63}$

57. Fifth Report of the Special Rapporteur, supra note 6, at 39-40. Sucharitkul noted that whether the tort was performed in the exercise of governmental authority or was a commercial act, the injured party had no way of preventing the injury, and could not be said to have assumed the risk of dealing with a sovereign state. Id.

In contrast, the FSIA's noncommercial torts exception preserves the special status of governmental functions. The exception does not apply to "any claim based upon thc exercise or performance or the failure to exercise or perform a discretionary function regardless of whether the discretion be abused." FSIA, 28 U.S.C. $\$ 1605(\mathrm{a})(5)(\mathrm{A})$ (1982). Congress intended the discretionary functions clause of the FSIA to mirror the Federal Tort Claims Act. See supra note 38.

58. See, e.g., supra notes $42-43$ and accompanying text (the "in whole or in part" clause).

59. See, e.g., supra notes 44-47 and accompanying text (the "presence" elause).

60. See supra notes $30-36$ and accompanying text.

61. See supra note 57 and accompanying text.

62. Id.

63. See FSIA, 28 U.S.C. $\$ \S 1609-1610$ (1982); State Immunity Act, 1978, art. 13; European Convention on State Imınumity, May 16, 1972, art. 23, Europ. T.S. No. 74, at 9; see also Seventh 
The discrepancy between immunity from jurisdiction and immunity from enforcement is particularly noticeable in the ILC draft. The ILC was clearly willing to restrict jurisdictional immunity as far as any of the recent codifications. Its provisions on enforcement, however, recognize a very broad rule of immunity, with exceptions so narrow that a successful judgnient creditor will have hittle hope of enforcing a judgnient agamst a foreign state unless the state willingly consents.

\section{A. Scope of the Immunity}

Article 21 of the ILC draft outlines the scope of a state's immunity from the enforcement of judgnients against it:

A State enjoys immunity, in connection with a proceeding before a court of another State, from ineasures of constraint, including any ineasures of attachment, arrest and execution, on the use of its property or property im its possession or control [, or property in which it has a legally protected interest,] . . . ${ }^{64}$

The language of the ILC draft differs from that of the FSIA and the State Immunity Act in three ways. First, the ILC draft employs the general phrase "nieasures of constraimt" to refer to the procedures from which states are immune. The FSIA specifically lists attachment, arrest, and execution, ${ }^{65}$ and the State Immumity Act mentions imjunction, order for specific performance or recovery of land, or any process for the enforcement of a judgnient or arbitration award, or arrest, detention, or sale in an ni rem action. ${ }^{66}$ The greater generality of the ILC draft provisions is not remarkable, however, because the Commission had to consider tlie varied metliods of enforcement employed by many different countries. ${ }^{67}$

Report of the Special Rapporteur, supra note 38, at 22; 1985 ILC Report, supra note 15, at 130 (noting that state practice clearly supports the rule that waiver of jurisdictional immunity does not imply waiver of immunity from measures of enforcement).

The European Convention provides much broader immunity from measures of enforcement than either of the national codifications. The Convention's broad enforcenent immunity, however, is based on the "special confidence subsisting among Members of the Council of Europe." CouNCIL OF EUROPE, EXPLANATORY REPORTS ON THE EUROPEAN CONVENTION ON STATE IMMUNITY AND THE Addimonal Protocol comment 7, at 9 (1972). See also G. BADR, supra note 30, at 130-31 (arguing that the community of attitudes among Council of Europe countries makes it practical to expect that the states will satisfy judgments voluntarily); Comment, Sovereign Immunity from Judicial Enforcement: The Impact of the European Convention on State Immunity, 12 ColuM. J. TransNaT'L L. 130, 148 (1973) (same). Since the special trust existing between the members of the Council of Europe does not exist between most nations, however, the Convention's broad enforcement immunity does not make a good model for a rule that operates generally. Consequently, this section of the Coinment will not refer extensively to the European Convention.

64. 1986 ILC Report, supra note 11, at 20 (brackets in origimal).

65. FSIA, 28 U.S.C. $\$ 1609$ (1982).

66. State Immunity Act, 1978, ch. 33, art. 13(2).

67. The Special Rapporteur origimally suggested the phrase "state immunity from attachment and execution." Seventh Report of the Special Rapporteur, supra note 38, at 43-44. Soune meinbers 
Second, the ILC draft's language on the immunity of a state with respect to the use of its property also differs fron the FSIA and the State Immunity Act. The two national codifications discuss the inununity of the property itself. The differences between immunity for use and imnunity for property, however, are more theoretical than practical. ${ }^{68}$ The effect of each approach is the same: to prevent the execution of judgments agaimst certain types of property.

The only substantive difference between the scope of enforcement immunity in the ILC draft and in the FSIA and State Imınunity Act is that the ILC draft includes within the rule of immunity property that is merely controlled by the foreign state. The Commission felt that the inclusion of language concerning control of property would help to determine which party enjoys immunity if a de facto or de jure government claims the property. By the terms of the draft, the state that controls or possesses the property has a claim to immunity. ${ }^{69}$ The Commission included the bracketed language in article 21 to cover cases where the foreign state has a legally protected imterest in property, but not ownership of it. ${ }^{70}$ As the use of the brackets indicates, however, the Commission has not decided whether or not to include the clause.

The ILC's provisions on the scope of immunity from enforcement reseinble the FSIA and the State Immunity Act in one important respect: each applies only to immunity of states froin court-ordered measures of

of the Commission were concerned, however, that the terms "attachment" and "execution" might have different meanings under the laws of different states. The ILC thus adopted the general reference to "measures of constraint," since it "would also mclude all other measures of judicial constraint under domestic law, inclnding certain types of interlocutory injunctions which might not be strictly considered 'attachment', 'arrest' or 'execution'." 1985 ILC Report, supra note 15, at 134.

68. The Special Rapporteur believed that there were important theoretical distinctions at stake:

Property is conceived as "object" rather than "subject" of rights or immunities. Indeed, the expression "property", whether "State property" or property in whieh a State has an interest, or property in the possession or control of a State, cannot be used as indicating a holder of rights or an owner or user of jurisdictional immunities in the same sense as the State or any one of its organs or agencies or even instrumentalities. It is therefore not strictly speaking property, as such, that is entitled to immunity.

Seventh Report of the Special Rapponteur, supra note 38, at 9.

69. See 1985 ILC Report, supra note 15, at 135.

70. Id. at 134-35. The ILC report illustrates the proposed immunity with the British case Dollfus Mieg et Compagnie S.A. v. Bank of England, 1949 Ch. 369, which involved a claim for specific restitution of gold ingots. The ingots were being held by the Bank of England for a joint commission estabhished by the United States, the United Kingdom, and France. The commission was to return nonmonetary gold looted by the German army during the Second World War. The bank could not claim sovereign immunity on its own account because it was not a government agency at the timc. The gold did not belong to any of the threc states involved. Yet the court held the bank immune from suit. The three states had a legally protected interest in the property, which was sufficient grounds for the court to deny rehief based on sovereign immunity. Id. at 385-92. 
enforcement. ${ }^{71}$ Although some members of the ILC argued that the articles should not be so limited, ${ }^{72}$ the Special Rapporteur felt that nonjudicial measures of constraint were beyond the scope of the ILC draft. ${ }^{73}$

\section{B. Exceptions to Immunity}

Article 21 hists only two types of property that are not immune from measures of enforcement: property intended for commercial purposes and property allocated to the satisfaction of a claim. Both of these exceptions to the general rule of enforcement immunity are drawn so narrowly that few tort plaintiffs would be able to benefit froin thein.

\section{The Commercial Purposes Exception}

Under the first exception, a court inay subject a foreigu state's property to ineasures of constraint if that property "is specifically in use or intended for use by the State for commercial [non-governmental] purposes and has a connection with the object of the claim, or with the agency or instrumentality against which the proceeding was directed."74 The first half of this provision tracks the State Immunity Act's commercial property exception, while the second half could only have been borrowed froin the FSIA.

All three versions of the commercial property exception demonstrate the difficulty in drafting a provision that would allow a court to distinguish commercial property from other property. Both the ILC draft and the State Immunity Act exempt property that is "in use or intended for use for commercial purposes." ${ }^{75}$ The parallel FSIA provi-

71. Nonjudicial measures might mclude execution, attachment, or seizure of property under an exeeutive order or legislative decree. See 1985 ILC Report, supra note 15, at 130.

The State Immunity Act concerns only immunity in the courts of the United Kingdom. The FSIA as well probably apphes only to immunity from judicial proceedings. One could argue that the FSIA permits immunity from executive or legislative orders: The general rule of enforcement immunity set out in $\S 1609$ is not limited by the language of the clause to judgments entered by courts. Cf. $\S 1604$ (addressing immunity from jurisdiction: "[A] foreign state shall be immune from the jurisdiction of the courts of the Umited States."). This construction is strained, however. The FSIA focuses on immunity from judicial proceedings. The very fact that the FSIA is in Title 28 of the U.S. Code, which regulates the judiciary, indicates that it is aimed at judicial proceedings.

72. See 1985 ILC Report, supra note 15, at 135.

73. See id. at 130. The Speeial Rapporteur did not explain precisely why the scope of the inquiry should be restricted to immumity from judicial measures of constraint.

74. 1986 ILC Report, supra note 11, at 20-21 (brackets in original).

75. The British Act states that the rule of immunity "does not prevent the issue of any process in respect of property which is for the time being in use or intended for use for commercial purposes." State Immumity Act, 1978, ch. 33, art. 13(4) (emphasis added).

Unlike the ILC draft, the State Immunity Act does not require that the property be "specifically" in use for commercial purposes. Nevertheless, if the head of a foreign mission certifies that property is not in use or intended for use for commercial purposes, that certification is "sufficient evidence" under the act "unless the contrary is proved." Id., art. 13(5). Thus, the scope of the term "commercial property" under the British act is probably no broader than under the ILC 
sion relates to property that "is or was used for the commercial activity."76 Both approaches have difficulties. The FSIA formulation requires a court to trace the origin of property to determine if the defendant state ever used it for a commercial purpose. The inquiry can be particularly burdensome $\dot{m}$ the case of fungible property, such as funds in a bank account. ${ }^{77}$ The framework of the British act and the ILC draft, on the other hand, presents the court with the equally difficult job of determining the defendant state's intent. ${ }^{78}$ While it is difficult to imagine a completely satisfactory method of separating commercial property from immune governmental property, the ILC's adoption of the State Immunity Act's approach did nothing to improve current codifications of the commercial purposes exception.

The ILC draft's second requirement-that the property have a connection "with the object of the claim, or with the agency or instruinentality agamst which the proceeding was directed"-tracks the FSIA rather than the State Immunity Act. The FSIA provides that property of the foreign state used for a commercial activity in the United States is not immune if "the property is or was used for the commercial activity upon which the claim is based."79 Property of agencies or instrumentalities of foreign states, however, is not immune from execution, so long as the agency does not have jurisdictional immunity with respect to the underlying clain. ${ }^{80}$ In suits agamst agencies, the FSIA does not require judg-

draft. See Fox, Enforcement Jurisdiction, Foreign State Property, and Diplomatic Immunity, 34 INT'L \& COMP. L.Q. 115, 117-23, 138 (1985) (discussing Alcolm Ltd. v. Republic of Colom., [1984] 2 W.L.R. 750, where the Law Lords restrictively construed article 13(4) to mean solely for commercial purposes).

76. FSIA, 28 U.S.C. $\S 1610(a)(2)$ (1982). Congress employed this construction in an effort to prevent recalcitrant foreign states from slifting assets to noncommercial uses to prevent execution of judgments. See House REPORT, supra note 23, at 28, reprinted in 1976 U.S. CODE CONG. \& ADMIN. NEwS at 6627 . Recent proposals to amend the FSIA recommend that this provision be changed to "is used or intended to be used" for commercial purposes. H.R. 1888, 100th Cong., 1st Sess. (1987).

77. For further discussion, see Delaume, The State Immunity Act of the United Kingdom, 73 AM. J. INT'L L. 185, 196-97 (1979), and Fox, supra note 75, at 132-40.

78. Professor McCaffrey suggests that the Frencl version of the ILC provision, "destinée," miglit be easier to discern than the English "intent." McCaffrey, supra note 14.

79. FSIA, 28 U.S.C. $\S 1610(a)(2)$ (1982) (empliasis added). The "upon wliticl the claim is based" language of the FSIA has generated a considerable amount of scliolarly comment. Some commentators approve of the nexus requirement. See, e.g., Fox, supra note 75, at 139-40; Note, Sovereign Immunity_Limits of Judicial Control-The Foreign Sovereign Immunities Act of 1976, 18 HARV. INT'L L.J. 429, 449-50 (1977). The latter coinmentator goes so far as to assert that the absence of a nexus requirement with respect to suits against agencies exceeds customary international law. Id. Conversely, other writers find the nexus requirement inore restrictive than customary international law requires. See, e.g., Crawford, Execution of Judgments \& Foreign Sovereign Immunity, 75 AM. J. INT'L L. 820, 862-63 (1981); Weber, The Foreign Sovereign Immunities Act of 1976: Its Origin, Meaning, and Effect, 3 YALE STUD. WORLD PUB. ORD. 1, 22-23 (1976).

80. FSIA, 28 U.S.C. $\$ 1610(b)(2)$. Thus, a plaintif who successfully prosecuted a 
ment creditors to establislı a nexus between their claim and the property they seek to attacli. ${ }^{81}$

Althouglı the ILC's provision is structured differently than the FSIA's provision, its effect is the same. ${ }^{82}$ A judgment creditor attempting to execute a judgment against the foreign state on property owned directly by the state must sliow a connection between the claim and the property. A judgment creditor atteinpting to execute a judgment against a foreign government agency on property of that agency need not slow any connection between the claim and the property.

The ILC's decision to adopt the FSIA nexus requirement was unfortunate, because the restriction prevents successful plaintiffs in noncoinmercial tort cases from using the commercial property exception to satisfy their claims. Letelier v. Republic of Chile ${ }^{83}$ illustrates this result. In 1978, agents of the Chilean government assassinated former Ambassador Letelier in the United States. After Letelier's survivors obtained a default judgment against Chile, they attempted to execute it on property belonging to the Chilean national airline. The Second Circuit denied the plaintiffs relief. It reasoned that Congress liad not intended the commercial property exception to apply to tort claims, and that in any case the airline's property liad no connection to the tortious act that formed the basis for the claim. ${ }^{84}$ The survivors could not execute the judgment.

The liarsli result of Letelier inust follow from requiring a nexus between the claim and the property because most noncommercial tort claims are not connected to any property. No property was connected to the claim in Letelier, for example, where the assassins used a boinb, or in Frolova v. Union of Soviet Socialist Republics, ${ }^{85}$ a claim for eniotional distress. ${ }^{86}$ By adopting tlie nexus requirement, tlie ILC draft works a

noncommercial tort suit against an agency of a foreign state could execute the judgment against all property of that agency in the United States, since agencies are not immune fron noncommercial tort claims by virtue of section 1605(a)(5) of the FSIA.

81. FSIA, 28 U.S.C. $\S 1610($ b)(2). One author, writing at the time Congress was debating the FSIA, found the discrepancy between the treatment of states and their agencies so imexplicable that he thought it might be the result of a drafting error. Note, The Immunity of Foreign Sovereigns in U.S. Courts-Proposed Legislation, 6 N.Y.U. J. INT'L L. \& PoL. 473, 494 (1973).

82. Although the ILC uses "connection with the object of the claim" rather than "upon which the claim is based," it still requires a nexus betwecn the clainı and the property; thus, the two provisions are substantively the same.

83. 575 F. Supp. 1217 (S.D.N.Y. 1983), rev'd, 748 F.2d 790 (2d Cir. 1984), cert. denied, 105 S. Ct. 2656 (1985). For further details on Letelier, see infra note 123 and accompanying text.

84. Letelier, 748 F.2d at 798. The FSIA's language compels the result and the legislative history supports the conclusion that Congress crafted the commercial property exception to benefit comnercial creditors. See House REPORT, supra note 23, at 28, reprinted in 1976 U.S. CODE CONG. \& ADMIN. NEws at 6627.

85. 761 F.2d 370 (7th Cir. 1985) (U.S. citizen narried to a Soviet citizen brought suit against the Soviet Union for emotional distress caused by its refusal to permit her husband to emigrate).

86. Of course, in some cases there might be property connected with the clain. A tort victim who is hit by a car might argue that the car that struck her is "property on which the claim is 
significant hardship on tort claimants. ${ }^{87}$

\section{Funds Allocated for Satisfaction of the Claim}

The second exception in the ILC draft provides that immunity from execution does not apply when the property "has been allocated or earmarked by the State for the satisfaction of the clain which is the object of that proceeding." 88 This clause, however, will not provide judgment creditors with inuch relief in the only cases where they need it: when foreign states refuse to pay judgments. Because the provision requires that a state earmark property for satisfaction of the claim that is the object of the proceeding, the foreign state, $m$ essence, unust consent to the execution of the claim. ${ }^{89}$

The ILC's provision appears to be even unore narrow than the FSIA, which denies immunity with respect to insurance policies by which the claim is covered..$^{90}$ Under the ILC draft, a state inust earmark property for satisfaction of the particular claim. A foreign state cannot, however, earmark insurance policies that cover general claims for the satisfaction of a particular claim until after the plaintiff brings suit. Consequently, even a general insurance poticy that covers the exact type of injury involved in a claim wonld be immune froin execution unless the foreign state indicated that the insurance funds could be used to satisfy the claim after the plaintiff filed suit.

The revised provision is thus so narrow that it seems pointless to include it at all. Execution of judgments is only a problem when the

based." However, the value of the automobile would not defray the costs of a serious injury, at least not in the United States.

87. The ILC's adoption of the nexus requirement cannot be justified by reference to widespread state practice, either. The United States seems to be the only country that employs a nexus requirement, and the proposed amendmeut to the FSIA would delete that requirement. H.R. 1888, 100th Cong., 1st sess. (1987). But cf. State Department Response to H.R. 1888, supra note 47, at 31 (noting that several unspecified states informed the State Department that they have a nexus requirement). When it engages in "progressive development" of international law, the Commission should be especially careful to produce a rule that will generally be equitable.

Part III of this Comment considers how the ILC could achieve a better balance between the interests the Cominission sought to protect by restricting the commercial property exception and the interests of poteutial tort claimants.

88. 1986 ILC Report, supra note 11, at 21.

89. In the Special Rapporteur's 1986 report, this provision read "has been allocated to a specific payment or has been specifically earmarked for payment of judgement or any other debts." Eighth Report of the Special Rapporteur, supra note 12, at 24. Thus, under the earlier draft, funds that the defendant state keeps in the fornm state for satisfaction of general debts and judgments would have been available to successful claimants, without the consent of the foreign state.

90. FSIA, 28 U.S.C. $\$ 1610$ (a)(5) (1982). The ILC, however, did not intend to deny tort claimants the benefits of insurance funds. During the debate on the noncommercial tort exception to jurisdictional immumity, sonie of the Commission's members noted that in a few jurisdictions tort plaintiffs are able to bring actions directly against insurance conipanies, thereby avoiding the problem of immuuity. 1983 ILC Report, supra uote 47, at 35. 
foreign state refuses to pay. When the foreign state cooperates to the extent this provision requires, enforcement is not a problem.

\section{Other Provisions Concerning Enforcement of Judgments}

Article 22 of the ILC draft provides that a state cannot invoke immunity from measures of constraint when it has consented to them by international agreement, contract, or declaration in the particular case. In this regard, it is similar to the State Immunity Act, which states that the general rule of immunity "does not prevent the giving of any relief ... with the written consent of the State concerned; and any such consent (which may be contained in a prior agreement) may be expressed so as to apply to a limited extent or generally." 91 The similarity is important: while the State Immunity Act is stricter than the ILC draft in requiring that a state consent to measures of constramt in writing, ${ }^{92}$ both codifications expressly provide that consent to the jurisdiction of a court does not constitute consent to measures of enforcement. ${ }^{93}$ The overall effect of these provisions is to encourage states to submit to the adjudicatory jurisdiction of foreign tribunals by making it more difficult to construe a court appearance as consent to enforcement measures.

Article 23 of the ILC draft provides additional protection from measures of execution to certam types of property that a foreign state might have abroad. By its terms, a forum state court cannot consider property to be in use or intended for use for a commercial purpose if: (1) the foreign state uses it to maintain a diplomatic or consular post; (2) the property is of a military character used or intended for use for military purposes; (3) the property is part of a central bank or monetary authority; (4) the property forms part of a state's cultural heritage or is part of its archives; or (5) the property is part of a scientific or historical exhibit not intended for sale. ${ }^{94}$ These types of property are thus absolutely immune from measures of enforcement unless the state consents or earmarks the property for satisfaction of a debt.

Exempting certain types of property from measures of constraint is not revolutionary, but the ILC draft exempts more types of property

91. State Immunity Act, 1978, ch. 33, art. 13(3).

92. The FSIA contains a more relaxed standard: A state may waive its immunity from measures of execution either expressly or by implication. 28 U.S.C. \$ 1610(a)(1) (1982).

93. State Immunity Act, art. 13(3); 1986 ILC Report, supra note 11, art. 22(2), at 21. The FSIA does not contain an express limitation to this effect. At least one lower court has found that waiver of jurisdictional immumity implied a waiver of immunity from enforcement proceedings. Hercaire Int'1, Inc. v. Argentina, 642 F. Supp. 126 (S.D. Fla. 1986), vacated on other grounds, 821 F.2d 559 (11th Cir. 1987). But cf. Letelier v. Republic of Chile, 748 F.2d 790 (2d Cir. 1984) (immunity from execution provisions must be separately waived), cert. denied, $105 \mathrm{~S}$. Ct. 2656 (1985).

94. 1986 ILC Report, supra notc 11, at 21-22. 
than either the State Immunity Act or the FSIA. Both national codifications exempt the property of a central bank, and the FSIA, like the ILC draft, exempts property of a military nature. ${ }^{95}$ The ILC draft is alone in exemptimg property that forms a part of a foreign state's cultural heritage or scientific or historical exhibits, although the State Immunity Act and the FSIA would probably exenipt such property on the ground that it is not "commercial property."

The ILC draft is also unique in exphcitly exempting diploniatic and consular property from enforcenient actions. The ILC probably included this provision to prevent forun states from seizing bank accounts that a state devotes only in part to the support of a diploniatic mission..$^{96}$ Although this restriction might provide an incentive for states to use embassy accounts for a variety of purposes, it also saves the courts of the forum state from trying to discover how a country uses the funds in its bank accounts. ${ }^{97}$

\section{Structural Differences Between the FSIA and the ILC Draft}

The ILC draft's provisions on execution of judgments are nuuch more restrictive than those in the State Immunity Act, yet the two codifications have similar structures. Both focus on the type of property involved in a suit in order to determine whether it is immune fron measures of execution. This approach has the advantage of smiplicity, but it is inflexible.

In contrast, the FSIA goes one step further. Like the other codifica-

95. State Immunity Act, art. 14(4); FSIA, 28 U.S.C. § 1611(b).

96. In Birch Shipping Corp. v. Embassy of Tanzania, 507 F. Supp. 311 (D.D.C. 1980), the court found that an account used to defray the expenses of Tanzania's embassy was not completely immune from enforcement jurisdiction because the account was also used for incidental purchases of goods and services not necessary for embassy upkeep. Compare the approach of the German Coustitutional Court in the Philippine Embassy Bank Account case:

The financial settlement of the costs and expenses of an embassy through a general current account of the sending State maintained with a bank in the receiving State pertains directly to the continued discharge of the diplomatic functions of the sending State, notwithstanding the fact that some transactions through such an account may, as regards relations with the bank or with third parties, be effected in the context of legal relationships or forms of activity which can, by their legal nature, be termed acts jure gestionis.

Judgment of Dec. 13, 1977, Bundesverfassungsgericht, W. Ger., 46 Bundesverfassungsgericht [BVerfGE] 342, 398-99, reprinted in MATERIALs ON IMMUNITIES, supra note 2, at 297, 318. By specifically including bank accounts used to maintain diplomatic missions in article 23, the ILC draft follows the approach of the German Constitutional Court. Interestingly, the proposed annendments to the FSIA take the opposite approach, sanctioning measures of enforcement against a bank account that is used for commercial purposes as well as maintenance of a diplomatic mission. H.R. 1888, 100th Cong., 1st Sess. (1987).

97. The difficulties such an evaluation would unpose on courts also support the State Immunity Act's rule that the certificate of the head of a mission that property is not used for a commercial purpose is sufficient evidence of the fact unless the contrary is established. See State Immunity Act, art. 13(5) (discussed supra note 75); see also Delaume, supra note 77, at 195-97 (assessing the merits of the State Immunity Act's approach to the problem). 
tions, the court focuses on the type of property the plaintiff seeks to attach. Only commercial property is available for satisfaction of judgments. Unlike the other two codifications, however, the FSIA requires that commercial property fit into one of five statutory exceptions before it can be attached. ${ }^{98}$

Significantly, four of the five exceptions contained in section 1610(a) are directly linked to provisions relating to jurisdictional immurity. (Subsection (1) allows attachment where the state waives immunity). For example, subsection (2), which provides an enforceinent reinedy to commercial claims creditors, mirrors section 1605 (a)(2), which exempts certam commercial claims from jurisdictional immumity. Subsection (3), which excepts froin enforceinent immunity certain judgments relating to property taken in violation of international law, is directly related to section 1605(a)(3), which exempts similar actions froin jurisdictional immumity. ${ }^{99}$

98. FSIA, 28 U.S.C. $\$ 1610$ (a) (1982). Compare the detailed provisions of the FSIA section on enforcement immumity to the shorter, simpler, and less adaptable provisions of the ILC draft: The property in the United States of a foreign state, as defined in section 1603(a) of this chapter, used for a commercial activity in the United States, shall uot be immune from attachment in aid of execution, or from execution, upon a judgment entered by a court of the United States or of a State after the effective date of this Act, if-

(1) the foreign state has waived its immunity from attachment in aid of execution or from execution either explicitly or by implication, notwithstanding any withdrawal of the waiver the foreign state may purport to effect except in accordance with the terms of the waiver, or

(2) the property is or was used for the commercial activity upon which the claim is based, or

(3) the execution relates to a judgment establishing rights in property which has been taken in violation of international law or which has been exchanged for property taken in violation of international law, or

(4) the execution relates to a judgment establishing rights in property

(A) which is acquired by succession or gift, or

(B) which is immovable and situated in the United States: Provided, That such property is not used for purposes of maintaining a diplomatic or consular mission or the residence of the Chief of such a mission, or

(5) the property consists of any contractnal obligation or any proceeds from such a contractnal obligation to indemnify or hold harmless for the foreign state or its employees under a policy of automobile or other hability or casualty insurance covering the clain which merged into the judgment.

Id. The ILC draft, in contrast, provides in relevant part:

A State enjoys immunity, in counection with a proceeding before a court of another State, from measures of constraint, including any incasures of attachinent, arrest and execution, on the use of its property or property im its possession or control [, or property in which it has a legally protected interest,] unless the property:

(a) is specifically in use or intended for use by the State for commercial [non-governmental] purposes and has a coimection with the object of the claim, or with the agency or instrumentality against which the proceeding was directed; or

(b) has been allocated or earmarked by the State for the satisfaction of the claim which is the object of that proceeding.

1986 ILC Report, supra note 11, at 20 (brackets in original).

99. Subsectiou (4), relating to property acquired by succession or gift and immovable property in the United States, and subsection (5), relating to attachment of insurance policy proceeds, similarly mirror jurisdictional immunity provisions in $\$ 1605$. 
The FSIA thus uniquely creates a close relationship between the scope of immunity fron execution of judgments and the scope of immunity fron adjudicatory jurisdiction. Although the ILC's Special Rapporteur originally intended to link enforcentent jurisdiction and adjudicatory jurisdiction, ${ }^{100}$ the final draft of the ILC's work largely failed in this regard. As Parts III and IV will demonstrate, this failure is unfortunate. It prevented the ILC from taking a inore equitable approach to the scope of immunity froin nieasures of enforcenent, which would have provided successful tort claimants with at least sonie ineans of satisfying their judgments.

III

\section{Policy Considerations IN THE ENFORCEMENT OF JUDGMENTS}

There are two principal reasons why inany states recoginize greater immunity froin measures of execution than they recoginze for adjudicatory jurisdiction. First, restricting immumity from measures of execution more directly threatens the core principles of sovereignty and equality than exercise of adjudicatory jurisdiction. If a court denies jurisdictional immumity to a foreign state, the foreign state inay refuse to recoginize the jurisdiction of the court. The court may issue a default judgment, but the foreign state can just as easily refuse to recognize the validity of the judginent. ${ }^{101}$ If, however, the foruin state seizes the foreign state's property to satisfy a judgment, the foreign state carmot protect its sovereignty and equality simply by ignoring the court's order. Second, refusing to recognize enforceinent immunity might prevent a foreign state from maintaining a diploinatic presence in the foruin state. If a forun state allows any property of a foreign state to be attached, a judginent creditor night seek to execute the judgment against property used to nuaintain the foreign state's enibassy or consulate. ${ }^{102}$

Codifications of sovereign immunity doctrine separate jurisdictional immunities from enforcement immumities because the drafters recognize that there are instances where the national interests of the foreign state

100. Seventh Report of the Special Rapporteur, supra note 38, at 23.

101. States conimonly engage in this sort of behavior. The United States, for example, refused to recognize the jurisdiction of the International Court of Justice in the Nicaragua case. United States: Statement on the U.S. Withdrawal from the Proceedings Initiated by Nicaragua in the International Court of Justice, 24 INT'L LEGAL MATERIALS 246 (1985) (reproduced from text provided by the U.S. Department of State). The Soviet Union did not enter an appearance in Frolova v. Union of Soviet Socialist Republics, 761 F.2d 370, 371 n.1 (7th Cir. 1985) (for a description of Frolova, see supra note 85), and Leteher v. Republic of Chile, 502 F. Supp. 259 (D.D.C. 1980) was a default judgment (for a description of Letelier, see infra note 123 and aecompanying text).

102. See 1985 ILC Report, supra note 15, at 132-33; G. BADR, supra note 30, at 107-08. 
outweigh the interests of the judgment creditor. In fashioning a rule on execution of judgments the primary pohicy question is not whether there should be a right without a reinedy, since clearly these rights can be counterbalanced by national interests of foreign states. Rather, the drafters should consider what circumstances justify withholding a reinedy. Resolving this question requires balancing several important interests: the digmity of the foreign state and its ability to maintain an effective presence in the forum state; the forum state's interest in enforcing its decrees and in inaintaining good relations with other states; and the interest of the successful plaintiff in receiving satisfaction for a judgment. ${ }^{103}$

The ILC's draft articles providing broad enforceinent immumity are simply not justified. The Commission's unduly heavy einphasis on the interests of foreign states virtually excludes the other important interests involved. Soine of the arguments advanced for broad enforceinent immunity have inerit. Yet they do not justify such a wide scope in all cases. The Coimmission erred by atteinpting to articulate a rule apphicable to all cases instead of developing a flexible structure that would take into account the differing interests that arise in each set of circumstances.

\section{A. ILC Debates on the Scope of Enforcement Immunity}

In his seventh report, ${ }^{104}$ Special Rapporteur Sucharitkul proposed several draft articles that would have restricted enforcement immumity even more than the analogous provisions of the FSIA. In essence, he proposed that a state be immune froin ineasures of execution except when: (1) the state has consented to the ineasures; (2) the state is using or imtends to use the property for commercial purposes; (3) the object of the proceedings is to determine ownership; or (4) the state has allocated the property for the satisfaction of a final judgment or payment of debts. ${ }^{105}$ Unlike the FSIA, the proposed articles did not contain an overarching requirement that only commercial property could be attached. Furtherinore, application of the Special Rapporteur's suggested commercial activity exception did not depend on proof of a nexus between the property and the claim.

The balance struck by the Special Rapporteur clearly favored the interests of judgment creditors and the courts of the forum state. The ILC's report indicates that his proposals provoked controversy among the Coimmission's ineinbers, some of whom felt that the approach taken by the Special Rapporteur:

did not sufficiently take into account the principle of the sovereign equal-

103. See 1985 ILC Report, supra note 15, at 134.

104. Seventh Report of the Special Rapporteur, supra note 38.

105. Id. at 43-44 (draft article 22). 
ity of States and the principle that State property could not be attached without the State's consent. This view suggested that Part IV [concerning enforcement measures] had overlooked the interest of the developing countries, where governments were obliged under their legal systems to conduct trade with foreign entities. The purpose of this type of foreign trade or "commercial activity" was not, however, "profit making" but mternal development, satisfymg the basic needs of their population. ${ }^{106}$

The Commission thus had two reasons for recognizing broad immunity from measures of execution: one theoretical, the other practical.

In theory, foreign states should enjoy wide immunity from measures of execution. If states are sovereign and equal, a forum state should not be able to force another state to obey the decree of the forum state's courts. Enforcement of judgments against unconsenting states is thus derogates from the principle of sovereign equality.

However, this absolutist position is untenable. Since foreign states operate within the forum state by the latter's consent in the first place, nothing in the ideal of sovereign equality suggests that the forum state's consent cannot be conditioned on willingness to satisfy valid judgments. ${ }^{107}$ Furthermore, as a practical matter broad enforcement immumity can promote irresponsible and unjust behavior on the part of foreign states. A state may behave egregiously, but stand safe behind its cloak of immunity. ${ }^{108}$ So long as immuinty from execution is not coextensive with immumity from adjudicatory jurisdiction, sovereign immunity will sometimes leave judgment creditors without remedies. Basing an immumity doctrine on the principle that a defendant state's consent is an absolute requirement to measures of constraint, however, will always leave plaintiffs without a means of satisfyimg their judgments against reluctant foreign state defendants. It is unlikely that foreign states would waive immumity or pay judgments in cases where the underlying claims are based on intentional wrongdomg by states or their agents. ${ }^{109}$

The Commission members' second argument is pragmatic. Developing countries must have extensive trade relations with developed nations.

106. 1985 ILC Report, supra note 15, at 133.

107. Even Chief Justice Marshall recognized that sovereign immunity is grounded in the forum state's consent:

The jurisdiction of courts is a branch of that which is possessed by the nation as an independent sovereign power. The jurisdiction of the nation, within its own territory, is necessarily exclusive and absolute; it is susceptible of no limitation, not imposed by itself. ... All exceptious, therefore, to the full and complete power of a nation, within its own territories, unust be traced to the consent of the nation itself. They can flow from no other legitimate source.

The Schooner Exchange v. McFaddon, 11 U.S. (7 Cranch) 116, 135 (1812).

108. The Letelier case provides the clearest example, but by no means the only one. See infra note 122 and aecompanying text.

109. The reactions of the Umited States to the Nicaragna decision and Chile to Letelier are illustrative. See supra note 101. 
As a state's contacts with other states increase, that country's potential for incurring legal habilities in contracts, torts, and other types of actions likewise increases. A rule inaking a state's commercial assets broadly available for execution of judgments could seriously impair a developing country's ability to maintain the commercial activities vital for its existence. ${ }^{110}$

Although the practical argument may be valid, the ILC has taken it too far. Admittedly, denying immunity for enforcenient of judgments against all commercial property could cripple the international commercial endeavors of developing countries. As the next section demonstrates, however, in solne cases the equities weigh against the foreign state, regardless of its econormic condition.

The ILC's report indicates that the Commission was unpersuaded by the doctrinal argument, but found the practical argument compelling. ${ }^{111}$ In any event, the Commission inodified the Special Rapporteur's proposals. The only real exception to mminnity left in the draft, aside froin consent, is for property used for a commercial purpose that is connected either with the claim or with an agency agamst which the claim was inade.

\section{B. Defining a Fair Level of Enforcement Immunity in Different Types of Cases}

The preceding sections have shown that the ILC's broad enforceinent immunity provisions are flawed. While codifications of sovereign immunity doctrine should not ignore the theoretical or practical ramifications of permitting execution of judgments agamst the property of sovereign states, there are other interests which also inust be weighed. The ILC attenipted to articulate a standard applicable to all types of cases that might arise. This is the draft's essential failing. The types of claims that can arise in international hitigation are diverse, and involve a different balance of interests. This section denionstrates that the practical con-

110. Despite his support for more restrictive provisions on enforcement immunity, Sucharitkul was keenly aware of the cogency of this argument:

[T] he disallowance of measures that threaten the very existence and survival of a State, especially a weaker, smaller and poorer State in the long process of national development, is a matter of life and death for an independent sovereign State. Immumity is consistent not only with the dignity of a State but also with the very concept of independent statehood. Without such immunity chaos may creep im as States are now obliged to keep certain funds and assets abroad and to own properties in foreign lands for various representational and governmental functions in addition to their international trade or commercial activities. Seventh Report of the Special Rapporteur, supra note 38, at 25.

111. 1985 ILC Report, supra note 15, at 133-34. The ILC report is written in a neutral, journalistic reporting style. Thns, it is difficult to tell which arguments persuaded the Commissiou. The fact that the ILC explained the practical argument very clearly, however, might indicate that the Commission found it persuasive, and the report's acknowledgement that immunity cannot be absolute undermines the doctrinal argument. 
cerns that prompted the ILC to adopt broad enforcement immunity are less compelling in tort cases than in commercial cases, while the interests of the fornm state and of the claimants are greater in tort cases, particularly when the tort is an act of international terrorism.

\section{Commercial Cases}

The ILC's broad enforceinent immuinty is inost appropriate in cominercial cases. The extreine exainple provided by the Nigerian cement cases $^{112}$ supports this conclusion. In 1975, the government of Nigeria began buying immense quantities of cement. "[T]he statistics speak for themselves. Nigeria executed 109 contracts, with 68 supphers. It purchased, in all, over sixteen million metric tons of ceinent. The price was close to one billion dollars." 113 Under the terms of its contracts, Nigeria was to establish in each seller's favor "an Irrevocable, Transferable abroad, Divisible and Confirmed letter of credit" through the bank designated by the seller in the contract. ${ }^{14}$ Nigeria chose instead to estabhish what it called "irrevocable" letters of credit with its own Central Bank. ${ }^{115}$

Nigeria expected that only $20 \%$ of the supphiers would perform. This was a serious miscalculation. Hundreds of ships bearing cement soon converged upon Nigeria, and its port facilities were not up to the task. By July 1975, the harbor at Lagos/Apapa held over 400 ships waiting to unload, and 260 of thein carried cement. With additional ships approaching and demurrage charges mounting, Nigeria took drastic action. It unilaterally altered the letters of credit, ordering the bank that handled Nigeria's banking in the Urited States not to pay any money on the letters of credit without prior authorization by its Central Bank. It then requested its supphiers to cancel all their outstanding contracts for dehvery of cement to Nigeria. ${ }^{116}$

The Nigerian case demonstrates the type of problem that concerned representatives of developing nations in the ILC debates. Analysis of the fact from the Nigerian perspective illuminates the concerns of the Commission. While the ceinent agreeinents were a commercial activity, the health and safety of Nigerian citizens was threatened because imports of vital food and materials could not unload in the overcrowded port. ${ }^{117}$

112. Many cases were brought against Nigeria in different countries and courts. Judge Kaufinan summarized the basic facts of the ceinent crisis in Texas Trading \& Milling Corp. v. Federal Republic of Nig., 647 F.2d 300, 302-06 (2d Cir. 1981), cert. denied, 454 U.S. 1148 (1982).

113. Id. at 303.

114. Id.

115. Id. at 304.

116. Id. at 305. Nigeria did not dispute the characterization of these actions as anticipatory breaches of contract. Id. at 306.

117. Lord Denning, in his characteristically blunt style, described the extent of the problein: 
Furthermore, although Nigeria ordered excessive amounts of cement because of a negligent or reckless miscalculation of market forces, it did not enter the contracts with any intent to harm the sellers. In cancelling the contracts because performance would have exacerbated health and safety hazards for it citizens, the government of Nigeria simply acted in accordance with its primary duty.

An additional factor makes this case a good illustration of the ILC's concerns. The stakes involved were enormous. One billion dollars is a large amount in any country. For a developing country like Nigeria, paying the disappointed contractors their expectation damages im an efficient breach may not have been a real option. ${ }^{118}$ Successful plaimtiffs would therefore be compelled to satisfy their judgments against Nigerian property in other countries. Exposure to execution of large judgments agamst its property on a global scale could seriously imipair Nigeria's ability to conduct foreign trade.

The forum state and the claimants also have important interests at stake. The forum state has an interest in having the valid judgments of its courts satisfied, and the transnational corporations have an interest im covering their losses and getting the benefit of their bargains. The corporate interests are less compelling in a commercial context, however. The corporations involved knew that they were dealing with a sovereign state. There are ways to protect their interests; indeed, inany of these were mcluded in the contract. When Nigeria issued the irrevocable letters of credit froin its own Central Bank imstead of the irrevocable, transferable, and divisible letters of credit by an independent bank of the seller's choice, the sellers had constructive notice that the transaction was less secure. Despite that notice, many proceeded with their contracts.

Commercial cases are fairly unique because the forum state, the foreign state, and the other parties to the contract all have soine ability to structure their relationship. An international codification of sovereign immuinty doctrime would be beneficial in the commercial context so long as it set out a clear rule, regardless of its substance. Whatever rules of sovereign immunity are $\mathrm{m}$ force, the parties will take these imto account when they draft their agreeinents. If jurisdictional and enforcement immumity is tightly circuniscribed, foreign states will be much inore hesi-

The ports were utterly unable to cope with [the cement]. Even for all commodities together, the discharging capacity at Lagos/Apapa did not amount to two million tons a year. Yet here was 10 times that amount arriving - of cement alone-leaving nothing for other vital imports of food and materials. The crisis was one of the reasons for a change of government in Nigeria. On July 29, 1975, a new military administration took over the reins.

Trendtex Trading Corp. v. Central Bank of Nig., [1977] I Q.B. 529, 548 (C.A.).

118. Note, however, that at the time, Nigeria was riding the OPEC boom, see, eg., T. BIERSTEKER, DISTORTION OR DEVELOPMENT? 76 (1978), and thus might have been able to satisfy a good portion of the potential judginent creditors. 
tant to make international contracts; if these immunities are broad, international busmesses will be more hesitant to deal with foreign states.

The ILC's broad rule of enforcentent immumity thus seems justified ni the context of commercial cases. Foreign states are not discouraged from engaging $\dot{\mathrm{n}} 1$ trade, which is particularly important for developing nations, and potential trading partners will scrutinize the state's past history of nivoking immunity, which will provide a check on foreign states' willingness to breach agreements.

\section{Accidental Torts}

The classic accidental tort case is the situation that the noncomniercial torts exception of the FSIA was particularly designed to meet: automobile accidents. ${ }^{119}$ In order to contrast the accident situation with the commercial context, suppose the Nigerian Ambassador to the United States struck a person while driving on the streets of Washington. Because diplomatic immunity shields the ambassador, ${ }^{120}$ the plaintiff would have to bring any clain for the tort against Nigeria.

The forun state has two interests at stake. The first, as in the contnercial case, is the satisfaction of valid judgments rendered by its courts. The second is its interest in protecting the health and safety of its citizens. Thus the forum state has a greater interest in tort cases than in contract cașes, indicating that a wider scope for execution of a judgment niay be appropriate.

The equities on the side of the claimant are also nuch stronger in the tort case than in the contract case. As noted above, parties to a contract generally have sone choice about whether to contract with governnients or their agencies. Before signing a contract with a foreign state, a conipany may determine whether the state generally keeps its agreements, what its financial status is, and even whether it imposes the defense of sovereign immunity frequently. Tort victims do not have the same opportunity. Their claims to full conipensation are correspondingly nuch stronger, because they lack the ability to protect theinselves.

Nigeria, of course, has a strong imterest in maintaining a diplomatic presence in foreign countries. Its ability to do so might be curtailed by a restrictive rule of immunity im noncommercial tort cases. While individual awards in torts cases generally do not reach the billion-dollar liability

119. See House RePORT, supra note 23, at 21, reprinted in 1976 U.S. Code Cong. \& ADMIN. NEws at 6620 ("The purpose of section $1605(\mathrm{a})(5)$ is to permit the victim of a traffic accident or other noncommercial tort to maintain an action against a foreign state to the extent otherwise provided by law."). Victims of traffic accidents are the only class of claimants specifically mentioned in the report.

120. Vienna Convention on Diplomatic Relations, Apr. 18, 1961, art. 31, 23 U.S.T. 3227, 3240, T.I.A.S. No. 7502, at 14, 500 U.N.T.S. 95, 112. 
involved in the Nigerian ceinent cases, the amounts involved are not necessarily small. The cuinulative effect of these judgments could be quite severe, and this result seeins particularly harsh because foreign states are less able to prevent the occurrence of accidental torts than to prevent breaches of their contracts.

When balanced agaimst the interests of the foruin state and the interests of the claimants, however, the interests of the foreign state appear less compelling. Foreign states can at least purchase hability insurance, and are in the best position to know what activities nost require it. Claimants have the least control over the situation and are most in need of a rule of immumity that protects their interests. Forum states have a great interest in protecting the health and safety of their citizens.

Therefore, to return to the hypothetical, if Nigeria refused to satisfy the judgment, it would be only fair to provide the claimant with an alternative remedy. Insurance policies might or might not offer a sufficient remedy. Simce they had no control over the foreign state's insurance coverage decisions, claimants should not be required to bear the risk that the msurance is insufficient. The real question, therefore, is what other property should be available to satisfy tort judgments.

The ILC draft's rule of broad immumity froin enforcement ineasures can produce an unjust and unnecessarily harsh result in noncommercial tort cases. This is particularly true because the ILC requires a nexus between the property and the claim. Since there is no property (except, perhaps, the automobile) that is connected to the claim, the foreign state actually has greater enforcement immunity in tort cases than it does in commercial cases. ${ }^{121}$ If anything, a proper balance of the different interests involved in commercial cases and tort cases should produce the opposite result: inore property should be available for enforcement of tort judgments than enforceinent of commercial clamis.

\section{State-Sponsored International Terrorism}

The balance of interests struck by the ILC's enforcement of judgments provisions makes the least sense in the context of tortious acts of international terrorism. The Letelier political assassination case provides a good occasion for examining the equities involved in sucli cases. ${ }^{122}$ In

121. See supra notes $82-87$ and accompanying text.

122. Letelier v. Republic of Chile, 488 F. Supp. 665 (D.D.C. 1980). Unfortunately, it is not the only example of tort cases caused by acts of international terrorism. See, e.g., Liu v. Republic of China, 642 F. Supp. 297 (N.D. Cal. 1986) (wrongful death action by wife of Henry Liu, allegedly assassinated by agents of the Taiwan government); Panel Orders France to Pay \$8.1 Million to Greenpeace, N.Y. Times, Oct. 3, 1987, at 2, col. 3 (noting result of recent international arbitration concerning the bombing of the Greenpeace vessel Rainbow Warrior in New Zealand by agents of the French government). Letelier is certainly one of the worst possible cases since it was an intentional killing; in contrast, the French agents who planted the bombs on the Rainbow Warrior did not intend 
1978, Orlando de Letelier, former Chilean Ambassador to the United States, was assassinated in Washington D.C. by agents of the Chilean government. ${ }^{123}$ Letelier's widow obtained a default judgment on lier tort claim against the Republic of Chile, which she attempted to execute by attaching property of the Chilean national airline in New York. The Second Circuit overruled the district court and held that the assets of the airline were not subject to execution to satisfy judgment against the Republic of Chile. ${ }^{124}$

The equities mvolved in determining whether Chilean property should have been available for execution of the judgment in Letelier differ from those in contract cases, or even accidental torts. Intentional acts of international terrorism are inatters of free clioice on the part of the foreign state. In contract cases, a state frequently is impelled by necessity in botl inaking and breaking contracts, as the Nigerian cement cases illustrate. Even in the case of accidental torts, the foreign state operates under certain constraints: for practical reasons, it inust maintain a diplomatic and consular presence in the foruin state, and accidents will occasionally occur because of that presence. If there are practical reasons coinpelling foreign states to engage in acts of international terrorism, lowever, international law does not currently recognize their legitimacy. ${ }^{125}$

The respect that a fornm state normally pays to the policy clioices of foreign sovereign states slould not extend to actions that flagrantly violate basic principles of international law. ${ }^{126}$ When the foreign state has

to kill anyone, although one person did die in the bombing. While these differences may add up to important moral distinctions, in the context of foreign sovereign immunity doctrine the cases are indistingnishable in their relevant details. In each, agents of a foreign state deliberately violated the territory of the forum state to commit tortious acts.

123. The Leteliers' attorney recently described the incident to a congressional committee: On September 21, 1978 Roumi Karpen Moffitt and her husband Michael Moffitt were traveling to work with their colleagne, Orlando Leteher, a former Chilean Ambassador who had been given refuge in [the Umited States]. As they entered Sheridan Circle a car bomb which had been covertly placed under the driver's seat of the car was detonated by a radio controlled device from a trailing automobile. The explosion resulted in the death of Mrs. Ronni Moffitt and Orlando Letelier and severe injuries to Michael Moffitt, the sole survivor of the automobile.

Foreign Sovereign Immunities Act: Hearing on H.R. 1888 and H.R. 1149 Before the Subcomm. on Administrative Law and Government Relations of the House Comm. on the Judiciary, 100th Cong., 1st Sess. 130 (1987) (testimony of Samuel J. Buffone, attoruey for the Letelier family) [hereinafter Buffone Testimony on H.R. 1888].

124. 748 F.2d 790 (2d Cir. 1984), cert. denied, 105 S. Ct. 2656 (1985).

125. See, eg., G.A. Res. 40/61, 40 U.N. GAOR Supp. (No. 53), U.N. Doc. A/40/53 (1986) ("unequivocally" condemning as "criminal" all acts, methods, and practices of terrorism "wherever and by whomever committed").

126. The district court in Letelier specifically derried that the assassination was a "discretionary function" witlin the ineaning of $\S 1605(a)(5)(A)$ of the FSIA, because "action that is clearly contrary to the precepts of humarity as recognized in both national and international law" is not within the discretion of a government official. Letelier, $488 \mathrm{~F}$. Supp. at 673. 
deliberately committed an actionable wrong in the territory of another sovereign, its pohicy choices should carry no weight. Subjecting it to the full judicial process of the forum state, both for jurisdiction and for enforcement, would be just under such circumstances.

While the legally cognizable interests of the foreign state are thus negligible in cases involving acts of international terrorisin, both the forum state and the victim have significant interests in ensuring satisfaction of the judgment in such situations. The forum state's interest reaches beyond the two interests involved in accidental tort cases, ${ }^{127}$ because it also has an interest in preventing dehberate violations of its laws and of international law. The victim of a terrorist act also has a strong interest in deinanding satisfaction of her claim by whatever property of the foreign state might be available. National and international law condemns acts of international terrorisin; people should be entitled to rely on these laws for their protection. When these laws are willfully violated, the victim is entitled to seek the aid of national and international law to ensure an adequate reinedy.

The ILC's provisions on immumity from execution are unacceptable in the context of state-sponsored international terrorisin, because they fail to balance the coinpeting interests of the foreign state, the forum state, and the victim. The victim should be able to attach any property of a foreign state that would be available for the execution of a commercial claim or an accidental tort. Indeed, the equities of the situation warrant a right even inore extensive than the right granted in commercial or accidental tort cases.

\section{Conclusions}

The three types of cases discussed above deinonstrate why it is too simple to treat all judgments alike for enforceinent purposes. The interests that inust be balanced have different weight in each type of case. It is inore appropriate to limit the types of property against which a judgment inay be enforced in commercial cases than in accidental tort cases. It is least appropriate to restrict recovery in cases where the foreign state has engaged in acts of international terrorisin. Thus, the principal flaw of the ILC's draft provisions on enforceinent of judgments is that they treat all cases alike.

Had the Commission used a limiting device other than the nexus requirement, it could have left soine types of property used for commercial purposes available for attachment in execution of tort judgments. ${ }^{128}$

127. In tort cases, the state has an interest in the satisfaction of valid judgments rendered by its courts and an interest in protecting the health and welfare of its citizens. See supra notes 119-21 and accompanying text.

128. The draft proposed by the International Law Association, for example, had a partial nexus 
Because the enforcement provisions apply equally to all kinds of claims, however, the ILC could not limit enforcement of commercial claims without limiting tort claims to at least the same degree.

If the ILC structured its enforcement provisions so that the scope of enforcement immunity depended to some extent on the type of case involved, the Commission could adjust the scope of enforceinent to reffect the equities involved in different types of cases. Part IV considers how such a structure might work.

\section{IV}

\section{Constructing a Flexible Enforcement Provision}

Had the ILC adopted the structure of the FSIA's enforcement provisions, it could have produced a rule on enforcement immunity that is more equitable than the provisions contamed in the current ILC draft, particularly in noncommercial tort cases. The FSIA links the scope of enforcement immunity to the type of claim involved. ${ }^{129}$ This structure permits the drafters to expand or contract the scope of inımunity based on the circumstances relevant to particular types of cases. As a result, a decision in a certain type of case will not affect the balance of interests applicable for other types of cases. ${ }^{130}$

This Part examines the question of what property should be available to satisfy judgments im particular types of cases. It concludes that an execution provision should allow commercial claimants to execute judgments against a foreign state's commercial property where that property is comected to the claim. The rule should also allow noncommercial tort clamiants to execute judgments against commercial property even though there is no nexus between the claim and the property. Additionally, the provision should permit victimis of state-sponsored acts of imternational terrorism to enforce their judgments against property owned by independent agencies of the foreign state, as well as any of the foreign state's commercial property in the forum state. Finally, no

requirement. Under its provisions, state-owned property was immune from attachment unless "[t]he property is in use for the purposes of commercial activity or was in use for the commercial activity upon which the claim is based." INTERNATIONAL LAW Assoc1ATION, supra note 35, at 10.

129. See supra notes $98-100$ and accompanying text.

130. A bill currently before Congress would amend the FSIA to permit execution of judgments in tort cases. H.R. 1888, 100th Cong., 1st Sess. (1987). Interestingly, it does so by eliminating the FSIA's separate provisions for separate claims. Under the new bill, a plaintiff can execute a judgment against any property of a foreign state that is in use or intended for use for a commercial purpose, regardless of the basis of the claim. Here, Congress appears to be throwing out the baby with the bathwater: the new bill could restrict enforcement immunity in tort cases by amending $\S 1610(a)(5)$ to permit tort plaintiffs to execute judgments against all commercial property without changing the structure of the entire Act. By constructing a single rule for execution of all judgments that is designed to produce an equitable result in tort cases, Congress makes the same mistake as the ILC, but in the opposite direction. 
plaintiff should be able to execute judgments against the property of a foreign state used for governmental purposes.

\section{A. Commercial Property}

Allowing enforcement against a foreign state's commercial property is not a radical idea. Many of the states that restrict enforcement immunity allow certain plaintiffs to satisfy judgments against the commercial property of a foreign state. ${ }^{131}$ A provision that permitted execution of judgments against all commercial property im all cases, however, might seriously inhibit a foreign country from making investments and engaging in other commercial activity abroad. ${ }^{132}$ Some limitation is necessary. A distinction based on the type of claim involved would provide a principled way to allow limited immunity. The drafter of a rule on immunity, therefore, should distimguish between enforcement of commercial judgments and enforcement of noncommercial tort judgments.

There are two principal reasons why an execution provision should limit the types of property upon which a commercial claimant may execute a judgment. First, allowing unlimited execution of judgments in commercial claims may seriously inhibit investınent by developing countries. Second, corporate claimants, unlike tort victims, have the opportunity to structure their relationships with sovereign states to protect themselves if they are injured. Moreover, corporations can elect not to deal with certain foreign governments, especially those that exhibit tendencies to interpose claims of immumity. ${ }^{133}$ Thus, an execution of judgments rule allowing commercial claimants to execute judgments only against commercial property comrected with their claim seems reasonable. The rule is not too harsh, since there is more likely to be property that satisfies a nexus requirement in a commercial case than in a tort case.

Despite foreign states' interest in engaging in international trade and investment, however, the rule should not completely immunize their commercial property from execution of noncommercial tort judgments. Claimants in noncommercial tort actions generally have no way to prevent their injuries from occurring, and should not be forced to bear the cost simply because agents of a foreign state happened to cause their injuries. Additionally, the forum state has a strong interest in protecting the

131. See, e.g., MATERIALS ON IMMUNITIES, supra note 2, at 578 (Kenya), 589 (Netherlands), 609 (Togo), 629 (U.K.), 636 (U.S.), 574 (West Germany). This source relies on responses to the questions: "[D]oes the property of a foreign State enjoy immunity from distraint or other forcible measures in aid of execution of a judicial decision? Is there any distinction based on the nature of or the use of the property involved?" Id. at 559.

132. See supra note 106 and accompanying text.

133. See supra notes 113-18 and accompanying text for a discussion of the interests involved in the Nigerian ceinent cases. 
health and safety of its citizens. ${ }^{134}$ Still, if claimants cannot execute their judgments against commercial property, they will often be unable to satisfy judgments unless the foreign state consents. ${ }^{135}$ Furthermore, there are few incentives for foreign states to pay judgments, apart from a narrow enforceinent immunity provision. ${ }^{136}$ Consequently, any execution of judgments provision for noncommercial torts should allow plaintiffs to execute tort judgments on the commercial property of foreign states. Since a nexus requireinent would leave hittle property available in most cases, it should be omitted for tort cases. ${ }^{137}$

\section{B. Property of an Independent Agency or Instrumentality}

Because inany countries conduct international commerce through independent state agencies or instrumentalities, ${ }^{138}$ an execution provision should outline the circunistances in which the property of these organizations is available for satisfaction of judgments against the foreign state itself. In the Uinited States, executimg judgments against a foreign country on property of one of that country's independent entities is similar to "piercing the corporate veil"; it can only be done in extraordinary circuinstances to prevent fraud or injustice. ${ }^{139}$ In applying this rule, the Second Circuit in Letelier v. Republic of Chile 140 held that "fraud or injustice" does not refer to the overall equities of the case, but refers instead to abuses of the corporate form. Thus, the court determined that a tribunal should only ignore the separate status of independent agencies when the foreign state exercises complete control over the agency, or establishes a separate entity to shield itself from tort hability. ${ }^{141}$

There are two primcipal reasons why the Uinted States discourages execution of judgments against foreign states on property of independent

134. For a full discussion of the interests of parties to tort cases, see supra notes 119-21 and accoinpanying text.

135. There are, of course, nonjudicial methods of responding to countries that abuse their immunity. The traditional method of settling claims against states is to go through diplomatic channels. State Department Response to H.R. 1888, supra note 47, at 33. While these nonjudicial methods might discourage foreign countries from too often or too flagrantly abusing their immunity, their application depeuds on the pohitics of the given situation. Therefore, they are not an adequate substitute for rational, moderate limitations on the principle of enforcement inununity.

136. In commercial cases, a country might be more inclined to pay judgments because failure to do so might complicate future commercial enterprises abroad. This incentive does not operate in tort cases.

137. See supra text accompanying notes 79-87.

138. "[M]ost states hold little commercial property abroad direetly; . . . most comnnercial property is in the lands of separate juridical entities, sucli as airlines and other state owncd commercial enterprises." State Department Response to H.R. 1888, supra note 47, at 29.

139. First Nat'l City Bank v. Banco Para El Coinercio Exterior de Cuba, 462 U.S. 61 1, 628 n.20 (1983) [hereinafter Bancec].

140. 748 F.2d 790 (2d Cir. 1984), cert. denied, 105 S. Ct. 2656 (1985).

141. Id. at 794 . 
agencies. First, as the Supreme Court has stated, courts generally should respect the decision of a foreign state to conduct business through independent agencies, if not out of deference to sovereignty then for reasons of comity. ${ }^{142}$ Reflecting this position, the FSIA does not allow plaintiffs to attach the property of one agency to satisfy a judgment against another agency, because such a practice might encourage foreign governments to disregard the independence of wholly owned subsidiaries of U.S. corporations. ${ }^{143}$

Second, the Supreme Court has observed that courts should respect the organizational choices made by foreign countries im an effort to proinote economic development:

Freely ignoring the separate status of government instrumentalities would result in substantial uncertainty over whether an instrnmentality's assets would be diverted to satisfy a claim against the sovereign, and might thereby cause third parties to hesitate before extending credit to a government instrnmentality without the government's guarantee. As a result, the efforts of sovereign nations to structure their governmental activities in a manner deeined necessary to pronnote economic development and efficient administration would surely be frustrated. ${ }^{144}$

Thus, a rule permitting a plaintiff to execute judgments against a foreign state on the property of that state's imdependent agencies would implicate the interests of foreign countries in imternational investment and commerce, as well as the imterests of third party investors. Furtherinore, the dainage to international imvestment resulting from application of such a rule would occur regardless of the size of the potential claims. Investors would be hesitant to deal with agencies of a foreign government that could be held responsible for activities over which they had no control. ${ }^{145}$ This result, coupled with the policy of respecting a foreign state's decision to transact business in the corporate form, weighs against a rule allowing claimants to execute contract judgments and most tort judgments against a foreign state on property of the agencies of those states.

These arguments are unpersuasive, however, when the claimant is the victim of state-sponsored imternational terrorisin. Although an enforcement rule should not discourage states from engaging im international imvestinent and commerce, neither should it protect them from the adverse consequences of dehiberate wrongful acts committed by their

142. Bancec, 462 U.S. at 626.

143. HousE REPORT, supra note 23, at 29-30, reprinted in 1976 U.S. CODE CONG. \& ADMIN. News at 6628-29.

144. Bancec, 462 U.S. at 626 (footnote omitted).

145. This factor distinguishes the Supreme Court's reasons for respecting the organizational choices of foreign states from the doctrinal and pragmatic concerns that drove the ILC to adopt a broad principle of immunity from all measures of enforcement. See supra text accompanying notes 106-11. 
agents abroad. Furthermore, while an enforcement provision might adversely affect third-party investors' interests if it permitted execution of judgments against an agency with which investors conduct business, such third-party interests inust be weighed against the interests of intentional tort victims in satisfying their judgments. Whereas investors can choose whether or not to associate with agencies of a foreign state, tort victims cannot. Limiting the rule to cases of state-sponsored international terrorisin would lessen the potentially harsh impact on investors, because they could consider a foreign government's propensity for engaging in terrorist activities when deciding whether to do business with one of its agencies.

The argument that permitting judgments against a state to be enforced against its agencies would encourage foreign states to disregard the separate status of the foruin state's corporate subsidiaries also is unpersuasive in the terrorisin context. A court's refusal to abide by a foreign state's corporate forms in such circuinstances would demonstrate no inore disrespect than refusing to abide by thein because the foreign state had abused the corporate form. In fact, if the exception were carefully drafted and embodied in an international convention, it might serve to affirm the general rule that corporate forms should be respected, while defining a limited special exception to the rule.

A rule permitting victims of state-sponsored international terrorism to execute judgments against property of wholly owned subsidiaries of foreign states therefore strikes a reasonable balance between the competing interests of the foreign state, the forum state, third parties, and the victim. ${ }^{146}$ The exception should, of course, apply only where a court has given a valid, binding judgment on the merits finding the foreign state responsible for committing a terrorist act within the forum state. ${ }^{147}$ In addition, it should be drafted in such a way that a successful tort plaintiff may only execute her judgment against property of an independent agency if that agency's state refuses to satisfy the judgment ${ }^{148}$ and has no

146. For a more thorough discussion of the balance of interests in cases involving international terrorism, see supra notes 122-27 and accompanying text. Sueh a rule, in addition to helping compensate victims, might help to deter acts of international terrorism by states. Singer, Terrorism, Extradition, and FSIA Relief: The Letelier Case, 19 VAND. J. TRANSNAT'L L. 57, 82 (1986) (suggesting that if tort claimants were able to execute judgments against a wide range of property in the United States, states might be deterred from committing terrorist acts in that country). Whether this would actually deter terrorist acts is questionable. The suggested restriction on enforcement immumity, however, is justified by the equitios involved without the deterrence rationale.

147. A complete definition of terrorist action is beyond the scope of this Comment. For the purposes of immumity doctrine, a possible wording might be: "an intentional noncommercial tort committed by an agent of a foreign state actiug on behalf of the government of the foreign state, performed in whole or in part in the forum state."

148. Refusal to pay a judgment is more likely, however, in a situation where the courts of one state have found that a foreign sovereign has behaved in flagrant breach of international law. See supra uote 101. 
commercial property of its own within the forum state. ${ }^{149}$

\section{Property Used for Governmental Purposes}

Noncommercial or governmental property used to maintain the presence of the foreign government im the forum state is normally immune from attachinent. ${ }^{150}$ Protecting this property is thus a compelling interest of botli the foreign state and the forum state, because the foreign state's presence allows both states to maintain diplomatic relations. Nothing in imternational custom currently allows plaintiffs to execute judgments against property of a foreign state that that state uses to maintain its diplomatic or consular presence im the forum state. ${ }^{151}$ Even those states that apply a rule of restrictive immunity to execution of judgments do not allow execution on diploinatic property. ${ }^{152}$

Allowing execution of judgments against this type of property would be a dehiberate affront to a foreign state, and could not be justified, even in the case of international terrorism. While the flagrant violation of imternational law negates the interests of the offending state, the interests of the forum state and the world commumity in preserving diplomatic relations are too weiglity to justify an exception to immunity.

\section{CONCLUSION}

Altlough the ILC draft recognizes that jurisdictional immunity of foreign states for noncommercial torts is inequitable, it fails to provide adequate means for redressing the injury caused by these torts. Under the draft's provisions, a successful claimant in a noncommercial torts case lias no way to satisfy his claim in court, unless the foreign state chooses to pay the judgment. The draft compels claimants to request that their governments sponsor their claims through diplomatic channels. ${ }^{153}$ This remedy depends on too many political factors to be a reliable and useful option-a point demonstrated by the survivors of the

149. One of the difficulties involved in formulating such a rule is defining an agency or instrumentality of a state for purposes of executing such judgments. Agencies coinpletely owned by the state should qualify. If there are minority investors, however, they would be unfairly injured if the agency in which they invested were included in the rule. In terms of the equities involved, such investors would be in roughly the same position as other innocent third parties dealing with the state agency; therefore, extending the rule to cover agencies in which the foreign state has a controlling interest would be appropriate.

150. See supra note $94-96$ and accompanying text.

151. Seventh Report of the Special Rapporteur, supra note 38, at 23.

152. See supra note 96 . Even the court that came closest to allowing execution of judgments against property used to maintain an embassy based its decision on the grounds that the bank aceount in question was not used exclusively for governmental purposes. Birch Shipping Corp. v. Embassy of Tanzania, 507 F. Supp. 311, 312-13 (D.D.C. 1980).

153. This is the traditional way of settling such disputes. State Department Response to H.R. 1888 , supra note 47 , at 33 ; see also supra note 135 . 
Letelier assassination, who are still seeking satisfaction for their claim against Chile nine years after the event, despite the continued assistance of the U.S. government. ${ }^{154}$

The Commission's provisions on enforcenent of judgments suffer from a lack of imagimation. The Commission borrowed language from the British State Immunity Act ${ }^{155}$ and the nexus requirement from the FSIA. ${ }^{156}$ The Commission should have borrowed the structure from the FSIA and independently examined the equities involved in the different types of claims. Had it done so, the Commission imght have produced a draft with less precedent in existimg practice, but with greater potential to produce equitable results in most cases.

However, the probleins with the draft articles may have as mucl to do with the limitations inherent in the Commission as with those inherent in the subject matter of the draft. The ILC is a small, professional commission; its members are not representatives of their country's views. Although the U.N. Charter and the Commission's own statute authorize and encourage the ILC to engage in progressive development of international law, ${ }^{157}$ it has engaged in very hittle progressive development during the course of its forty-year existence, preferring wherever possible to formulate and codify rules reflecting existing state practice. ${ }^{158}$ The Chairman of the ILC, Professor Stephen McCaffrey, noted that the Commission's reluctance to diverge too sliarply from current practice is well founded:

[The Commission] cannot do whatever it feels like, irrespective of whether the result will be acceptable to states. It reports to, and is governed by, the United Nations General Assenıbly, and would disregard trends of thought and reaction in the GA at its peril. This is a major reason for the overall success of the ILC's work. ${ }^{159}$

The ILC draft is not a convention yet, and may never be. Currently the ILC is waiting for comments from states on the draft. ${ }^{160}$ Once it has received the comments, the Commission unay revise the provisional draft, or adopt it on second reading, or even table consideration of it. Additionally, only the General Assembly may call a conference to consider a

154. Buffone Testimony on H.R. 1888, supra note 123, at 130-32.

155. See supra note 75 and accompanying text.

156. See supra note 79 and accompanying text.

157. See supra notes $9 \& 14$.

158. UNITED NATIONS INSTITUTE FOR TRAINING \& RESEARCH, supra note 13 , at 5.

159. McCaffrey, supra note 14; see also UNITED NATIONS INSTITUTE FOR TRAiNing \& RESEARCH, supra note 13, at 5 (noting that some members of the Commission feel that reform of international law should be considered by other organs of the U.N. where states are represented as states).

160. McCaffrey, Current Developments: The Thirty-Eighth Session of the International Law Commission, 81 AM. J. INT'L. L. 668, 668-69 (1987). 
convention. ${ }^{161}$ Thus many opportunities remain to reconsider the ILC draft. If the General Assembly decides to call a conference to consider the draft, such a conference would provide a more appropriate forum to consider different approaches to the difficult problem of enforcement than the Commission itself: a conference need not be bound by existing practice. Hopefully a conference would be moved to correct the injustice to tort victims reflected in current state practice and built into the ILC draft.

M.P.A. Kindall*

161. The procedure the ILC follows when it is considering draft multilateral conventions is set out in article 17 of its statute. ILC Statute, supra note 9, at 108, art. 17.

* A.B. 1985, University of California, Riverside; third-year student, Boalt Hall School of Law, University of California, Berkeley. I would like to thank Professor Stefan Riesenfeld, Peter Trooboff, and Professor Stephen McCaffrey for their helpful comments and suggestions. 


$$
\checkmark
$$

